7) The respiratory function of the testicles showed the most remarkable dimution of all endocrine glands.

8) The longer the hyperglycemic phase became, the more the respiratory function of the testicles was hindered.

9) The more remarkable was the hyperglycemic condition, the more the respiratory function of testicles was hindered.

10) From the facts above mentioned, it is concluded that alloxan diabetes is not only pancreatogenic, but polyglandular diabetes participated by various endocrine glands such as hypophysis, adrenal cortex and testicles.

Chapter III. The Influence of the Serum of Alloxan Diabetic Rabitts on the Respiratory Function of Organic Tissues

I investigated the influence of the serum of alloxan diabetic rabitts upon the respiratory function of organic tissues of ordinary mice, comparing with that of the serum of ordinary rabitts and at the same time pursued the study of the influence of the serum of diabetic patients upon the respiratory function of organic tissues. Lastly I experimented the influence of the serum of alloxan diabetic rabitts at the hypoglycemic convulsionary phase.

I concluded as follows :

1) The serum of normal persons and normal rabitts remarkably accelerate the respiratory function of cerebral cortex, lungs, liver and renal cortex.

2) The serum of diabetic persons accelerated the respiratory function of organic tissues, but its degree was smaller compared with the serum of normal persons.

3) The serum of alloxan diabetic rabitts accelerated the respiratory function of orgnic tissues. The degree of acceleration was found greater than caused by that of ordinary rabitts.

4) Between the serum at the hypoglycemic convulsionary phase and that of persistent hyperglycemic phase, no difference could be found upon the respiratory function.

5) No poisonous material was found in the serum of alloxan diabetic rabitts such as found in the serum of diabetic patients.

6) Not concerning with the blood suger level, the tendency was recognized of accelerating the respiratory function compared withe contrast.

7) Alloxan diabetes and human diabetes are not considered to have the same course.

\title{
Studies on the Aberration of Living Body with Tuberculosis
}

\author{
Especially the Aberration of Splenic Function Caused by Infection \\ with Tuberculosis, Indicated by the Salt-Fever
}

\section{Shozo MORI and Satoru FUNATA}

Department of Pathology, Tottori University School of Medicine

1) If normal rabbits were injected 5 per cent solution of $\mathrm{NaCr}$ in a dose of $1 \mathrm{cc}$ per $\mathrm{kg}$ of their bodyweight (a small dose), or $4 \mathrm{cc}$ per $\mathrm{kg}$ (a great dose), or 5 per cent solution of $\mathrm{CaCl}_{2}$ in a dose 
of lcc per $\mathrm{kg}$ of their bodyweight (a small dose), or $4 \mathrm{cc}$ per $\mathrm{kg}$ (a great dose), the following responses were manifested; they did not react to a small dose of Na-stimulus and reacted with a fever to a great one, and also reacted with a fever to a small dose of Ca-stimulus and with a fall of their body temperature to a great one. But, if the rabbits were infected with tuberculosis by the method of pouring tuberculous bacilli into their trachea, they showed the following responses after 22-24 days later, when tuberculin reaction became positive, they did not react to both a small and a great dose of Na-stimulus and to a small dose of Ca-stimulus and then reacted for the first time with a fever to a great dose of the latter.

This abnormal reaction of the salt-fever indicated that the rabbits with tuberculosis became dull to the salt-stimuli.

2) If normal rabbits were injected the serum of the rabbits with tuberculosis in a dose of $3 \mathrm{cc}$ per $\mathrm{kg}$ of their bodyweight and examined their responses to the afore-mentioned salt-stimuli 20 minutes later, they showed the abnormal reaction of the salt-fever as the rabbits with tuberculosis.

This fact indicated that active factors, which made positively the responses to the salt-stimuli dull, were generated in the blood of the rabbits with tuberculosis.

3) These active factors were found in a high grade in the splenic venous blood of the rabbits with tuberculosis at the earlier stage, when the tuberculin-reaction had not yet become positive and the action of these factors had not been observed so strongly in the general blood. These disappeared from the blood in the rabbits with tuberculosis by their splenectomy. If the spleen of the rabbits with tuberculosis was transplanted to a normal rabbit, the afore-mentioned abnormal reaction of the salt-fever became to occur in the latter, but the rabbits with tuberculosis that were transplanted with a spleen of normal rabbits showed again a former and normal reaction of the salt-fever.

It was indicated by these experiments that these active factors were products of the aberrated splenic function as a result of infection with tuberculosis.

\title{
Clinical Observations of Diabetes Insipidus
}

\author{
(2nd Report): Statistical Analysis of the Etiology \\ By
}

\section{Teruo OMAE and Yoshimi MURAKAMI}

From the Second Department of Internal Medicine (Director: Prof. G. Kusunoki), Kyushu University School of Medicine

The etiology of 269 cases of diabetes insipidus which have been reported in Japanese literatures since 1927 was analized statistically, and the following results were obtained:

(1) Causative diseases and their frequency: Idiopathic 116 cases $(43.1 \%)$, symptomatic 105 cases (39.0\%), familiary 27 cases (10.1\%) and others 21 cases (7.8\%). Among symptomatic cases neoplasms were 51 cases, being the highest, and Hand-Schüller-Christian's disease 18 cases, syphilis 16 cases, during pregnancy and following delivery 11 cases, trauma 5 cases, tuberculosis 3 cases and encephalitis 1 case. 


\title{
結核症に於ける生体の変調に関する研究
}

\author{
特に塩類熱を指標とした脾臟機能の変調に就いて一
}

\author{
舁取大学医学部将理学教等 (指導 故 德光教授)
}

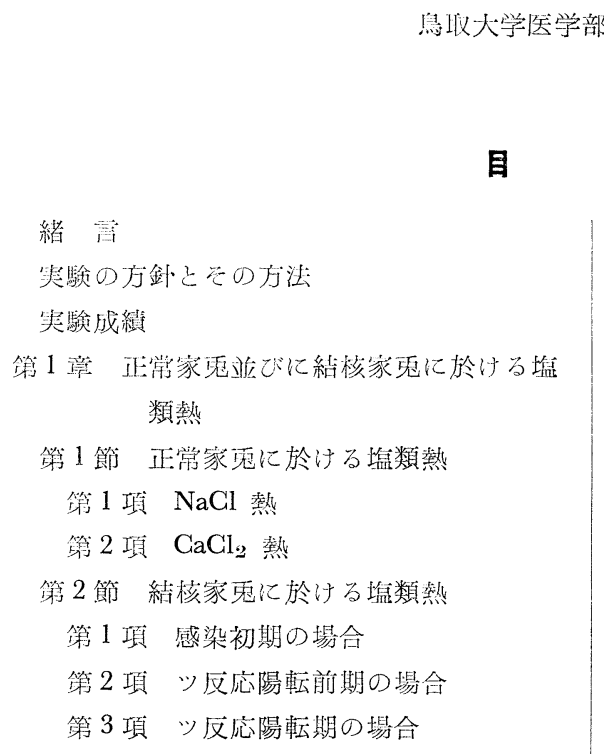

第 2 章 結核家鬼血清が他健常家鬼の塩類熱 に及ぼす影響並びにその血清内作用 因子の理化学的性状

第 1 節 結核家鬼の耳静脈血清老以て前処 瑱された正常家鬼に於ける塩類熱 第 1 项 感染初期結核家鬼の血清の作用 籍 2 項 ツ反応陽転前期結核家鬼の血清
森正 三，船田覚

\section{次}
の作用
第 3 項 ツ反応陽転期絬核家鬼の血清の 作用

第 2 節 結核家蒠血清内に出現する塩類熱 抑制性作用因子の理化学的性状

第 1 項 エーテル溶解性実験

第 2 項 血清蛋白分劃実験

第3 章 結核家鬼流血中に出現する㙁類熱抑 制性作用因子の産生藏器

第 1 節 結核家鬼の脾臓摘出害験

第 2 節 結核家鬼脾静脈血中の塩類熱抑制 性作用因子の出現

第 3 節 結核家鬼脾蔵の他健常家鬼への移 植轶験

第 4 節 結核家兔に於ける健常家鬼脾蔵の 移植実験

総括並びに考按

結 論

\section{緒言}

從来諸疾患の症状を解明するに当つて生体の藏器機能の量的变化のみ莡重視して, その機能の克進或いは

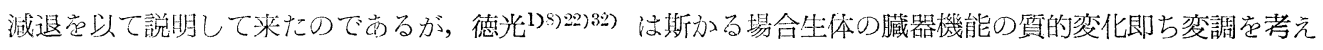

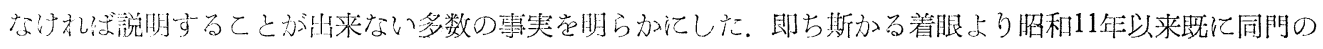

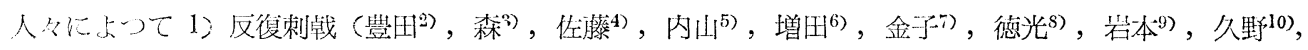

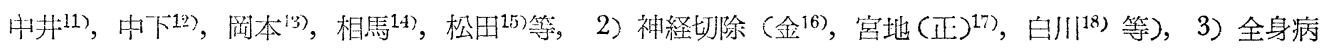

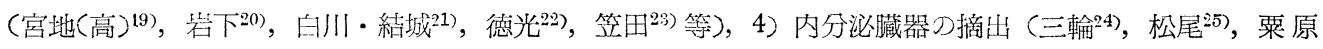

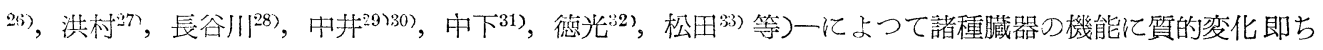

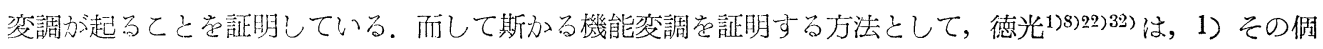
体に或種の刺㦸を加光た場合に健常個体の反応と異なつて無反応乃至逆反応等の異常反応を呈するとと,

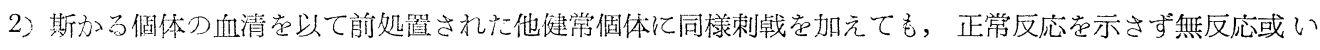
结逆反応等刀異常反応を起す, 即ち前処置血清中に斯かる反応を起させるような或種の作用物質の存在が認 わられ，乙の作用物質は或藏器の静脈血内に最も多く且早期に現われ，乙の臓器を摘出すると直ちに一般流

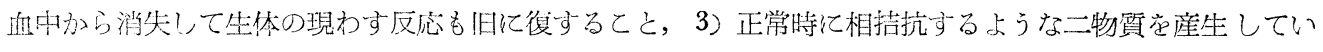




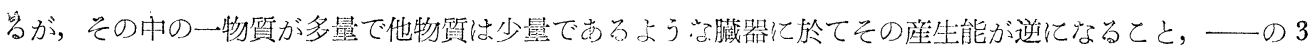
条件の中 2 条件証証明すれば，その藏器機能に変調が起つていると言うととが出来ると述へている。例えば

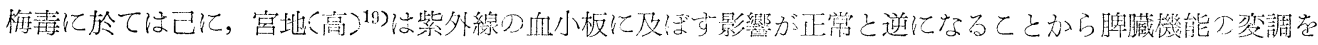

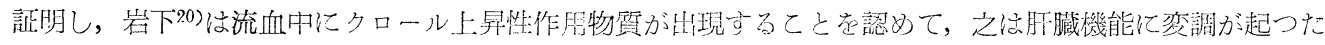

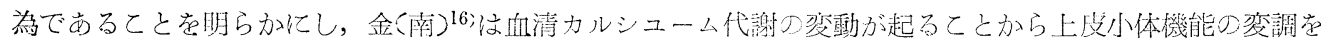

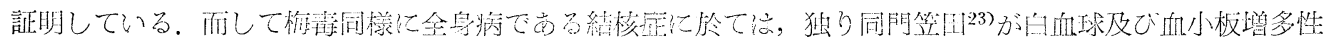

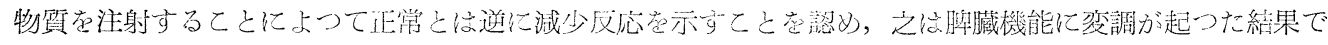

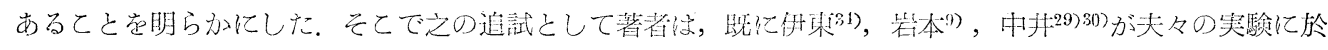

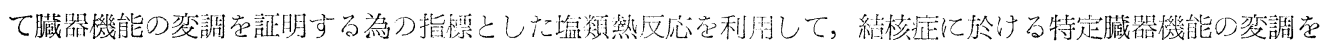
証明せんと本実験学試みたのである。

\section{実験の方針とその方法}

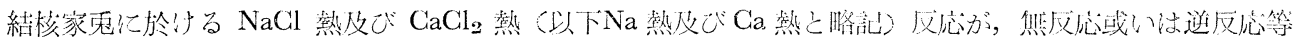

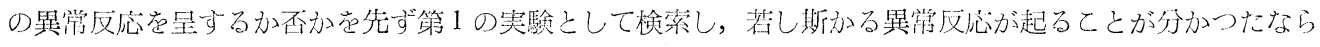

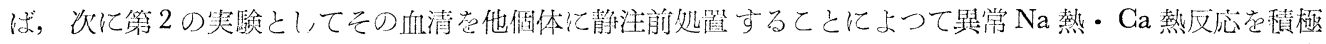

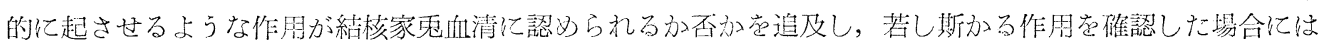

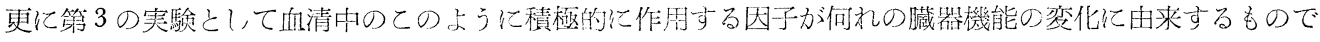
あるかを究明年るとととした。

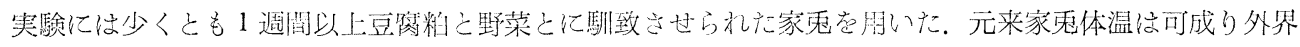

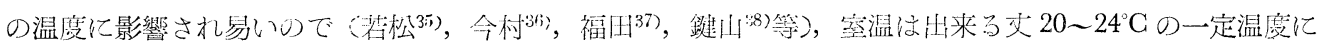

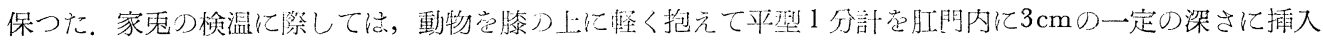

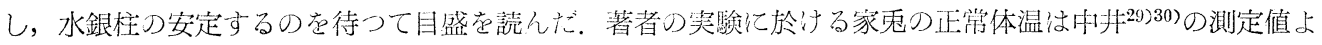
り稍々低く, 岩本 ${ }^{3}$ の測定值に略々一致した佔, 即ち $38.5 \pm 0.4^{\circ} \mathrm{C}$ が大部分であつた。亦日次的, 時間的家

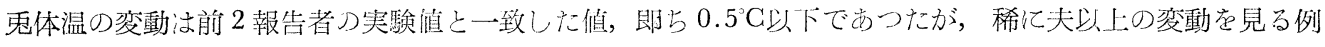

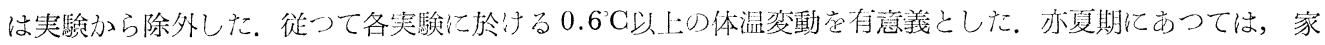

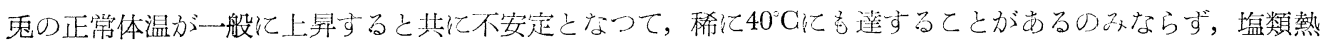
特に Ca 熱は屡々不安定となるので，乙の时期仙実駼を行わなかつた。

塩類熱反応つ刺战源として用いた $\mathrm{NaCl}$ 及び $\mathrm{CaCl}_{2}$ 㹥共代 $5 \%$ 溶液として家鬼に耳静脈内注射を行つた

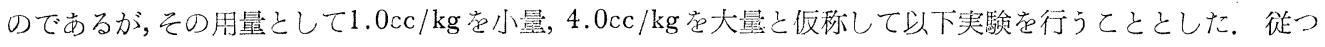

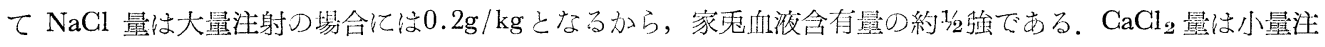

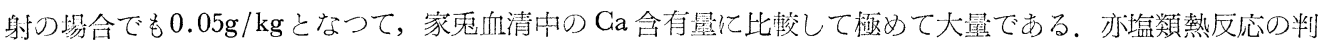

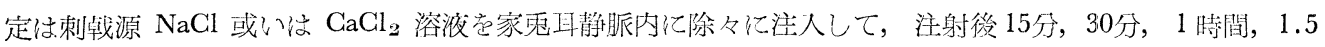

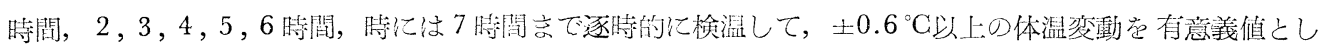

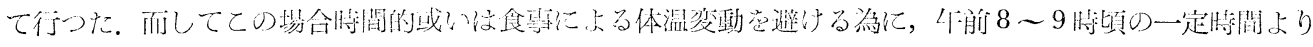

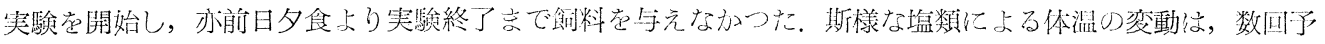

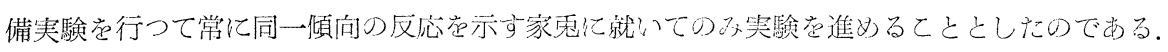

結核感染方法; 結核菌虫米子医大(現鳥取大学知学部) 細苜学教室与り分与された松本㧣人型結核菌乳淮

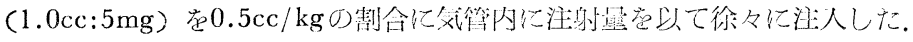

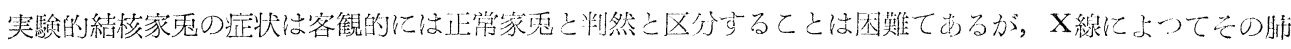

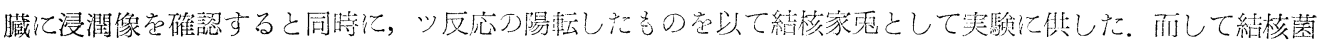

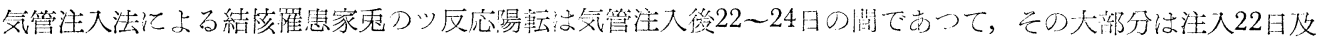

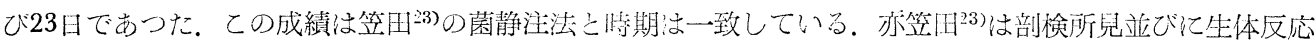
を参照して便宜上次の 3 期䎲分類しているので，著者名笠田の実験との刘比上ての分類に從つた。 
1) 感染初期：結核菌父管注入㷋 13 日迄にして，ッ反応(10\%ッベルクリン液を对う)が陰性であるばかり でなく，その他客観的に全く無症状な時期。

2) ッ反応陽転前期：菌気管注入後 14〜21日の期間にして，ッ反応泣未だ陰性であるが客観的症侯として 食欲稍々減退して軽度の体重減少觉見る時期。

3) ツ反応陽転期：菌気管注入後略々 22 23 日目にしてッ反応は陽転し，以後殊に食欲の減退と其に活動

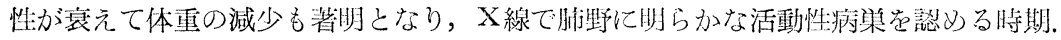

\section{実 験 成 績}

\section{第1章 正常家鬼並びに結核家鬼に於ける塩類熱 \\ 第 1 節＼cjkstart正常家兔の塩類熱}

\section{第 1 項 $\mathrm{NaCl}$ 熱}

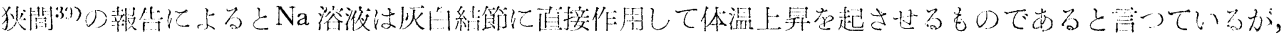

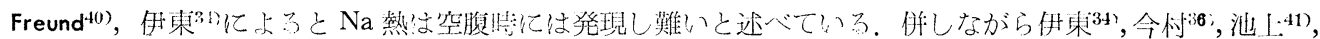

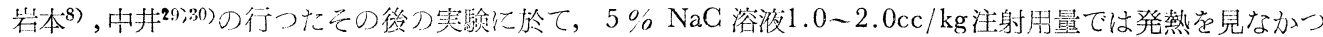

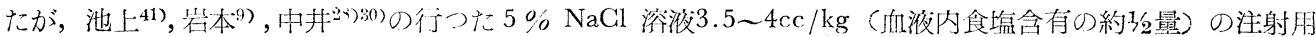
量に於ては，発熱を明ら汃認正价。

著者は以上の報告成績を追試確誌する為に，以下 $\mathrm{NaCl}$ 溶液注射に上る㙁類熱実験を行つた，即ち正常家 鬼に $\mathrm{NaCl}$ 溶液を小量 ( $5 \%$ 溶液 $1 \mathrm{cc} / \mathrm{kg}$ ) 及び大量 ( $5 \%$ \% 溶液 $4 \mathrm{cc} / \mathrm{kg}$ ) を注射して逐時的に休温変動を検

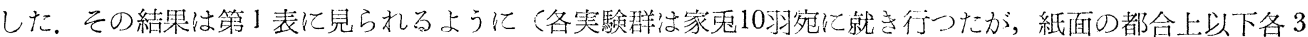

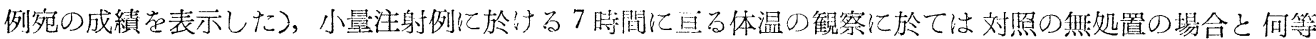
異なるととなく+0.2〜 - $0.1^{\circ} \mathrm{C}$ の範囲の動摇を見るに過ざなかつたが，大㽬注射例に於ては注射後 $0.5 〜 1$

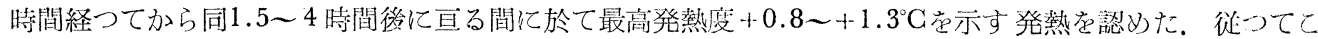
の成績は池上 ${ }^{49}$, 岩本 ${ }^{9}$, 中井 ${ }^{29} 300$ の実験成績に一致した結果であつた。

第 1 表 正常家医の無処置の場合に於ける一日中の体温の逐時的变動（対照） 及び小量並びに大量注射例の $\mathrm{Na}$ 熱反応 (単位 ${ }^{\circ} \mathrm{C}$ ) (室温 $20 \sim 24^{\circ} \mathrm{C}$ )

\begin{tabular}{|c|c|c|c|c|c|c|c|c|c|c|c|c|c|c|c|c|}
\hline \multirow{2}{*}{$\begin{array}{l}\text { 家番 } \\
\text { 乘号 }\end{array}$} & \multirow{2}{*}{$\begin{array}{l}\text { 体 } \\
\text { 重 }\end{array}$} & \multirow{2}{*}{\multicolumn{2}{|c|}{$\begin{array}{c}\text { 時間 } \\
\mathrm{NaCl} \text { 量 } \\
\end{array}$}} & \multicolumn{5}{|c|}{ 塩 } & \multicolumn{3}{|l|}{ 類 } & \multicolumn{3}{|l|}{ 熱 } & \multirow{2}{*}{$\begin{array}{l}\text { 発 } \\
\text { 熱 } \\
\text { 度 }\end{array}$} & \multirow{2}{*}{$\begin{array}{l}\text { 嘴 } \\
\text { 考 }\end{array}$} \\
\hline & & & & 前 & $15^{\prime}$ & $0.5^{\circ}$ & $1^{\circ}$ & $1.5^{\circ}$ & $2^{\circ}$ & $3^{\circ}$ & $4^{\circ}$ & $5^{\circ}$ & $6^{\circ}$ & $7^{\circ}$ & & \\
\hline 1 & 1900 & 無処置 & & 38.6 & 38.5 & 38.6 & 38. & 38 & 38 & 538 & 38 & 38.5 & 6 & 38.6 & $\begin{array}{l}+\quad 0 \\
-0.2 \\
\end{array}$ & \\
\hline 2 & 2000 & 同 & & $38.3^{\prime}$ & 38.3 & 38.4 & 38.4 & 38.1 & 38.2 & 38.4 & $\begin{array}{l}1 \\
+ \\
\end{array}$ & 38.3 & 38.2 & $|38.2|$ & $\begin{array}{l}+0.1 \\
-0.2\end{array}$ & \\
\hline 3 & 2000 & 同 & & 38.5 & 38.6 & 38.5 & 38.5 & 38.6 & $\mid 38.7$ & 38.7 & 38.5 & 38.6 & 38.6 & 38.5 & $\begin{array}{l}+0.2 \\
-0.1 \\
\end{array}$ & \\
\hline 4 & 2100 & 小 & 星 & 38.4 & $\mid 38.3$ & 38.3 & 38.3 & 38.43 & 38.4 & 38.5 & 38.4 & 38.4 & $|38.3|$ & 38.4 & $\begin{array}{l}+0.1 \\
-0.1 \\
\end{array}$ & 無反応 \\
\hline 5 & 2000 & 闹 & I: & 38.4 & 38.5 & 38.5 & 38.4 & 38.5 & 38.4 & 38.4 & 38.3 & 38.4 & 38.5 & 38.4 & $\begin{array}{r}+0.1 \\
-0.1 \\
\end{array}$ & 無反心 \\
\hline 6 & 2200 & 同 & 上: & & & 38.4 & 38.5 & 38.4 & 38.4 & 38.4 & 38.3 & 38.5 & 38.2 & 38.3 & $\begin{array}{l}+0.2 \\
-0.1 \\
\end{array}$ & 無反闷 \\
\hline 7 & 1900 & 大 & 鼠 & 38.1 & 38.2 & $\{38.4$ & 39.0 & 39.2 & 39.3 & 39.2 & 39.4 & 39.0 & 38.6 & 38.2 & +1.3 & 発 熱 \\
\hline 8 & 2000 & 间 & 1: & 38.5 & 39.1 & 39.3 & 39.2 & 39.2 & 39.2 & 39.0 & 39.0 & 38.8 & 38.6 & 38.5 & +0.8 & 発 熱 \\
\hline 9 & 1900 & 同 & 上 & 38.3 & 38.8 & 39.1 & 39.1 & 38.9 & 39.0 & 39.0 & 38.9 & 38.7 & 38.5 & 38.3 & +0.9 & 発 熱 \\
\hline
\end{tabular}


第 2 項 $\mathrm{CaCl}_{2}$ 熱

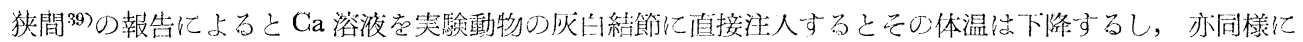
耳静脈内に注射しても体温下降を来たすてとを明らかにしている。高橋 ${ }^{42}$ は $\mathrm{CaCl}_{2}$ 溶液小量注射によつて

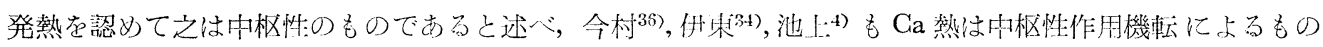

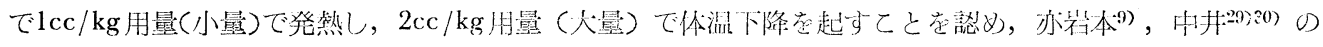

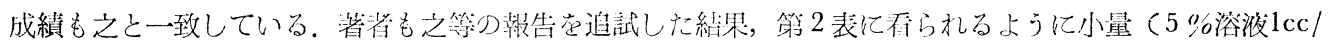

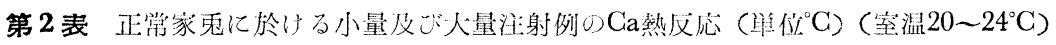

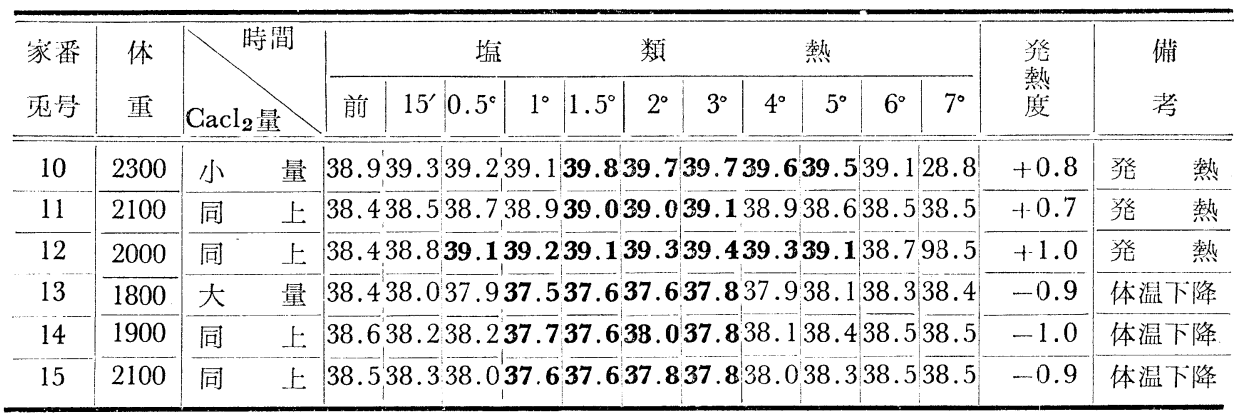

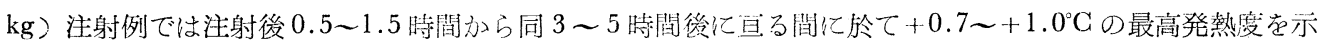
す発熱觉認め，亦大量 $(5 \%$ 溶液 $4 \mathrm{cc} / \mathrm{kg})$ 注射例では注射後 1 時間から同 3 時間後に亘る間に於て最大下

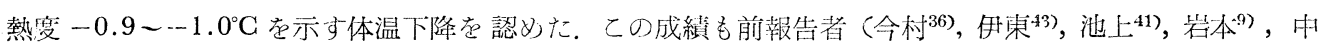
井2930)の諸成績と一致した結果であつた.

\section{第 2 節 結核家鬼に於ける塩類熱}

第 1 項 感染初期の場合

前節に於て行つたと同様に結核感染初期家鬼(菌気管注入後 5 日目) に前記同様に Na 溶液の小量及び大 量並びに Ca 溶液つ小量及び大兒を耳静脈内に注射して逐時的にその体温の変動を観察した。 その結果は第 3 表に示されているように正常家鬼に於ける同様実験つ成績と多ど差異を認めることが出来なかつた.

第 3 表 感染初期結核家鬼の檌類熱（菌気管注人後 5 日日）(室温 $20 \sim 24^{\circ} \mathrm{C}$ ) (单位 ${ }^{\circ} \mathrm{C}$ )

\begin{tabular}{|c|c|c|c|c|c|c|c|c|c|c|c|c|c|c|}
\hline 家番 & 体 & 時 間 & & 塩 & & & 類 & & & 熱 & & & 発 & \\
\hline 雭号 & 重 & 注: 射 物 & 前 & $15^{\prime} \mid 0.5^{\circ}$ & $1^{\circ}$ & $1.5^{\circ}$ & $2^{\circ}$ & $3^{\circ}$ & $4^{\circ}$ & $5^{\circ}$ & $6^{\circ}$ & $7^{\circ}$ & 度 & 劣 \\
\hline (4) & 1900 & $\mathrm{NaCl}$ (小㫫) & 38.5 & 38.538 .4 & 38.6 & 38.6 & 38.5 & 38.6 & 38.6 & 38.4 & & & $\begin{array}{l}+0.1 \\
-0.1\end{array}$ & 正常反応 \\
\hline$(5)$ & 1800 & 上 & 38.5 & 38.438 .5 & 38.5 & 38.5 & 38.53 & 38.6 & 38.4 & 38.5 & & & $\begin{array}{l}+0.1 \\
-0.1 \\
\end{array}$ & "I \\
\hline (7) & 1900 & $\mathrm{CaCl}_{2}$ (大量) & 38.3 & 38.639 .0 & 38.9 & 39.2 & 39.33 & 39.4 & 39.2 & 38.6 & $|38.4|$ & 38.3 & +1.1 & 正掌学反灾 \\
\hline (9) & 1900 & 上 & 38.5 & 38.838 .93 & 39.3 & 39.4 & 39.23 & 39.0 & 38.7 & 38.4 & 38.6 & 38.5 & +0.9 & " \\
\hline (10) & 2300 & $\mathrm{CaCl}_{2}$ (小量) & 38.8 & 39.139 .33 & 89.5 & 39.6 & 39.53 & 39.2 & 39.2 & 39.13 & 39.2 & 39.0 & +0.8 & 正常反応 \\
\hline (12) & 2000 & 上 & 38.3 & 38.638 .93 & 39.0 & 39.0 & 38.93 & 39.1 & 38.7 & 38.5 & & & +0.8 & 11 \\
\hline (13) & 1800 & $\mathrm{CaCl}_{2}$ (大睹) & 38.2 & 38.238 .03 & 37.6 & 37.5 & 37.63 & 37.43 & 37.4 & 37.6 & $|38.1|$ & & -0.8 & 正常反応 \\
\hline (14) & 1900 & 上 & 38.4 & 38.238 .13 & 37.9 & 37.7 & 37.83 & 38.0 & 38.0 & 38.13 & 38.3 & & -0.7 & "1 \\
\hline
\end{tabular}


第 2 項 ツ反応陽転前期の場合

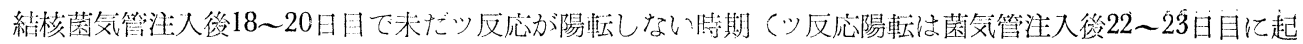

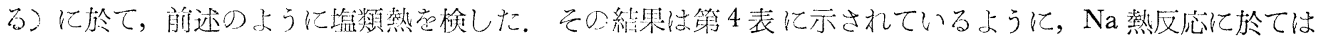

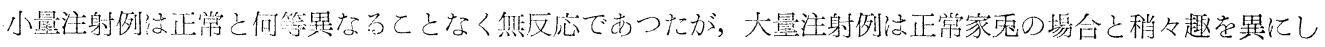

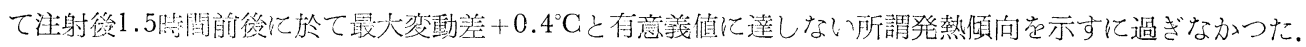

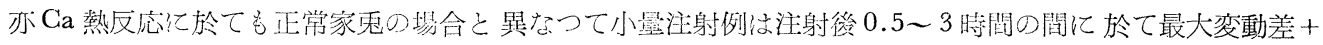
$0.4 \sim+0.5^{\circ} \mathrm{C}$ と有意我侮化達しない所謂発熱傾向走示すのみであつて, 亦大量注射例も注射後 $1 \sim 2$ 時間に

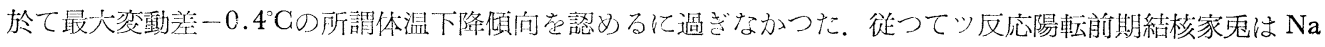
熱及び $\mathrm{Ca}$ 熱々対し其に稍々鈍くなる傾问を示すすのてあると思われた。

第4 表 ツ反応陽転前期結核家鬼の塩類熱(菌気管注入後18～20日目) (路位 ${ }^{\circ} \mathrm{C}$ ) (空温 $20 \sim 24^{\circ} \mathrm{C}$ )

\begin{tabular}{|c|c|c|c|c|c|c|c|c|c|c|c|c|c|c|c|}
\hline \multirow{2}{*}{$\begin{array}{l}\text { 家番 } \\
\text { 霓晃 }\end{array}$} & \multirow{2}{*}{$\begin{array}{l}\text { 休 } \\
\text { 正 }\end{array}$} & \multirow{2}{*}{ 時 間 } & \multicolumn{5}{|c|}{ 㷪 } & \multicolumn{2}{|l|}{ 類 } & \multicolumn{4}{|c|}{ 熱 } & \multirow{2}{*}{$\begin{array}{l}\text { 発 } \\
\text { 熱 } \\
\text { 緊 }\end{array}$} & \multirow{2}{*}{$\begin{array}{l}\text { 倩 } \\
\text { 考 }\end{array}$} \\
\hline & & & Hîj & $5^{\prime}$ & $0.5^{\circ}$ & $1^{\circ}$ & $1.5^{\circ}$ & $2^{\circ}$ & $3^{\circ}$ & $4^{\circ}$ & $5^{\circ}$ & $6^{\circ}$ & $7^{\circ}$ & & \\
\hline (4) & 1900 & $\mathrm{NaCl}$ (小量) & 38.3 & 3 & 2 & $20-5$ & is & 38 & 3 & 38 & 38.3 & 3.4 & & $\begin{array}{r}+0.2 \\
-\quad 0 \\
\end{array}$ & 正常反応 \\
\hline (5) & 1800 & 上 & 38.3 & 38.4 & 38.43 & 38.3 & 98.3 & 38.3 & 38.25 & 38.2 & 38.5 & 38.3 & & $\begin{array}{l}+0.2 \\
-0.1\end{array}$ & "1 \\
\hline (7) & 1900 & $\mathrm{NaCl}$ (大量) & 38.2 & 38.3 & 38.03 & 38.5 & 38.6 & 38.3 & 38.4 & 38.3 & 38.2 & 38.1 & 38.2 & $\begin{array}{l}+0.4 \\
-0.2 \\
\end{array}$ & 発熱傾向 \\
\hline (9) & 1900 & 上 & 38.3 & 38.5 & 38.63 & 38.73 & 38.63 & 38.7 & 38.53 & 38.3 & 38.4 & 38.2 & 38.2 & $\begin{array}{l}+0.4 \\
-0.1 \\
\end{array}$ & 11 \\
\hline (10) & 2300 & $\mathrm{CaCl}_{2}$ (小量) & 38.7 & 38.9 & 39.13 & 39.0 & 39.03 & 39.1 & 39.13 & 39.1 & 39.0 & 38.8 & 38.7 & $\begin{array}{r}+0.4 \\
-\quad 0 \\
\end{array}$ & 発熱傾向 \\
\hline (12) & 2000 & 上: & 38.4 & 38.5 & 38.93 & 38.83 & 38.73 & 38.6 & $38.9^{i}$ & 38.73 & 38.5 & 38.5 & & $\begin{array}{l}+0.5 \\
-\quad 0\end{array}$ & "1 \\
\hline (13) & 1800 & $\mathrm{CaCl}_{2}$ (大量) & 38.3 & 38.2 & 38.03 & 37.9 & 38.0 & 37.9 & 38.13 & 38.2 & 38.3 & 38.4 & & $\begin{array}{l}+0.1 \\
-0.4 \\
\end{array}$ & $\begin{array}{l}\text { 体温下降 } \\
\text { 傾向 } \\
\end{array}$ \\
\hline (14) & 1900 & 上 & 38.3 & 38.3 & 38.13 & 37.93 & 38.03 & 37.9 & 38.23 & 38.03 & 38.1 & 38.3 & & $\begin{array}{l}+\quad 0 \\
-0.4 \\
\end{array}$ & "I \\
\hline
\end{tabular}

\section{第 3 項 ツ反応陽転期の場合}

第 5 表 ツ反応陽転期結核家鬼の塩類熱 (ツ反応陽転後 $2 \sim 3$ 日目) (是位 ${ }^{\circ} \mathrm{C}$ ) (室温 $20 \sim 24^{\circ} \mathrm{C}$ )

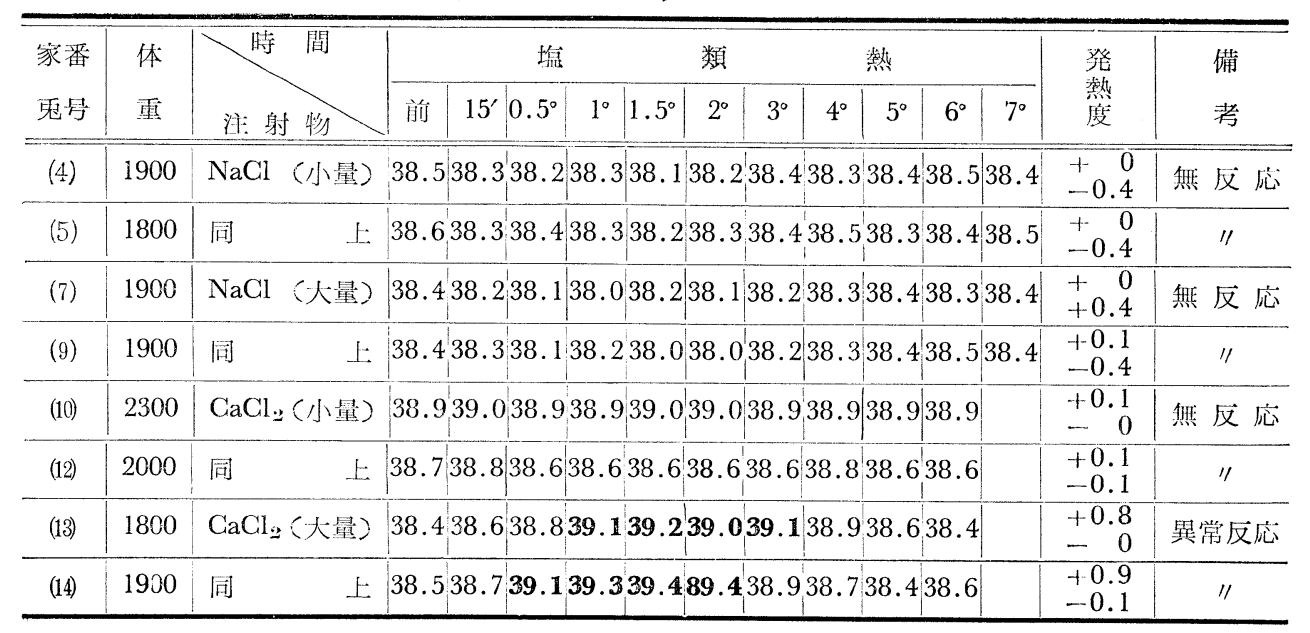


結核菌気管注入後22２3日目に於て，大部分のものはツ反応力陽忶してX線像に於て肺野に浸潤所見が認

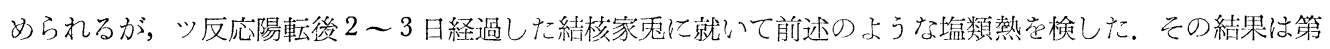
5 表に示されているように，正常家鬼の場合と全く異なつて，Na 熱反応代於ては小量及び大量注射共に注

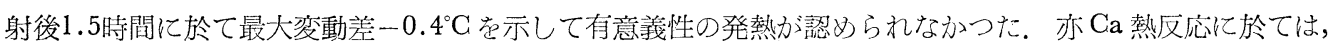

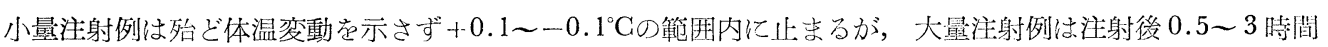
の間に於て最高発熱度 $+0.8 \sim+0.9^{\prime} \mathrm{C}$ 有意義性の発熱走示した。即ち $\mathrm{Ca}$ 大量注射例に於ては正常の場合 とは逆に発熱を見るが， $\mathrm{Ca}$ 小量及び Na 小量並びに大量注射例は何れも無反応であつた。従つてッ反応陽転

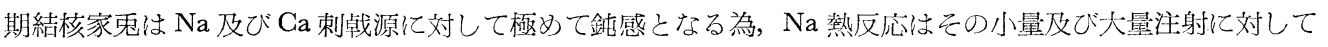
共侮反応であつて, Ca熱反応は大量注射によつて始もて正常家鬼の小量注射例と同様な発熱を示し, 小量 注射では全く反応を示さなかつた。

\section{本章の小括}

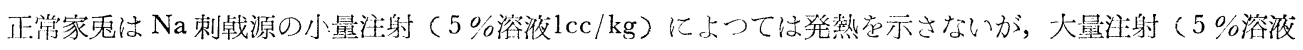
$4 \mathrm{cc} / \mathrm{kg})$ 飞よて発熱寺示し, 亦 $\mathrm{Ca}$ 刺战源の小量注射 $(5 \%$ 溶液 $1 \mathrm{cc} / \mathrm{kg})$ につて発熱苍来たし, 大量 注射 ( $5 \%$ 溶液 $4 \mathrm{cc} / \mathrm{kg}$ ) によつて体温の下降を来たすてと著者は先ず第一に追試して確喼したのであ

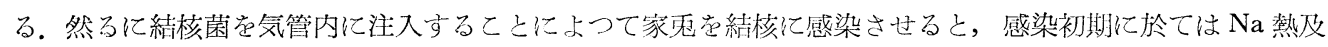
び $\mathrm{Ca}$ 熱反応共に正常家鬼反応と全く異ならないが，ッ反応陽転前期に至ると Na 熱反応に於てはその小量 注射対しては反応を示さないととは前同様であるが，大量注射に対しても発熱の傾向を示すの及となり， 亦 $\mathrm{Ca}$ 熱反応に於てもその小量注射刘して余り体温の上昇は見られず発熱傾向を示すのみであり，大量注 身利しても休温の下降は少くその倾向を見るのみとなる．即ち斯かる時期に於ては $\mathrm{Na}$ 熱及び $\mathrm{Ca}$ 熱反応

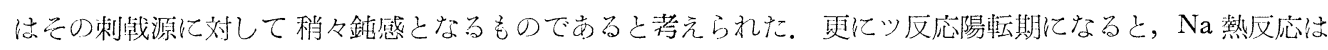
その小量或いは大量の刺战源に対して共に反応范示さず，亦 $\mathrm{Ca}$ 熱反応はこの刺㦸源の小量に刘して反応を 示さないが，大量に対して正常家鬼の小量注射の場合の上うに発熱するようになる. 即ちツ反応陽転期結核

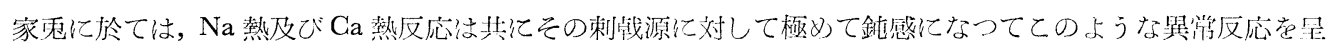
するものと思われる。

\section{第 2 章 結核家鬼血清が他健常家兔の塩類熱に及ぼす影響並びに その血清内作用因子の理化学的性状}

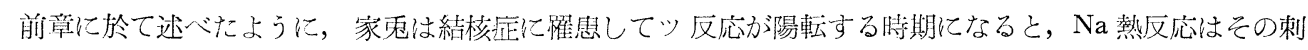
战源の小量及び大㝵に刘して共に無反応であつて, 亦 $\mathrm{Ca}$ 熱反応もその刺㦸源の小量に刘して無反応であつ て大量に刘して正常家鬼の小量注射の場合の上うに発熱するてと学認めた．斯くの如く結核家鬼が Na 熱及

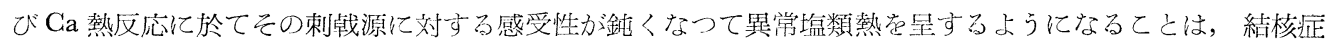

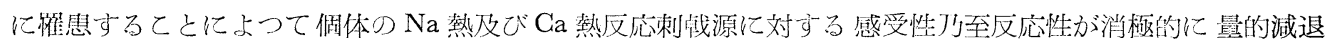
を来たした為のものであるか，或いは斯かるる湖体の反応总積極的に抑例する上うな作用因子がその血清中に 出現する為のものであるか危検索する必要がある。即ち結核家免の血清に斯かる作用があるか如何かを梌索

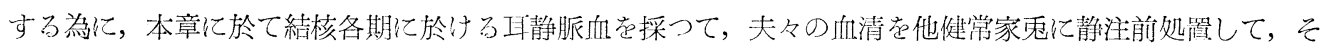

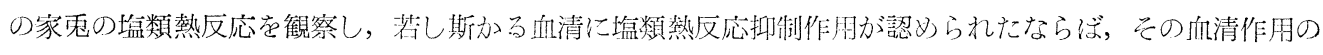

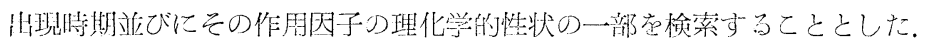

\section{第 1 節 結核家鬼の耳静脈血清を以て前処置された正常家鬼に於ける塩類熱}

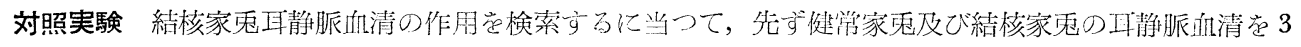

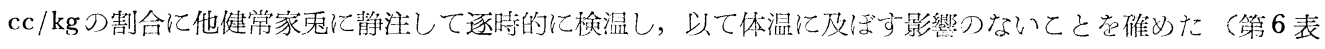

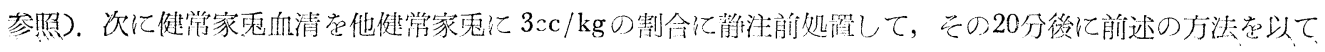


㙁類熱反応を検した。その結果は第 6 表に示されているように，健常家鬼が㑑清注射の前処置を受けなかつ

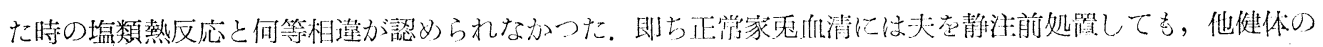
塩類熱反応に何等影響虑与えるような作用が浔められなかつた。

第 6 表 正常家鬼血清学以て前処置された正常家鬼の前处置20分後に於ける 㙁類熱 (単位 ${ }^{\circ} \mathrm{C}$ ) (室温 $20 \sim 24^{\circ} \mathrm{C}$ )

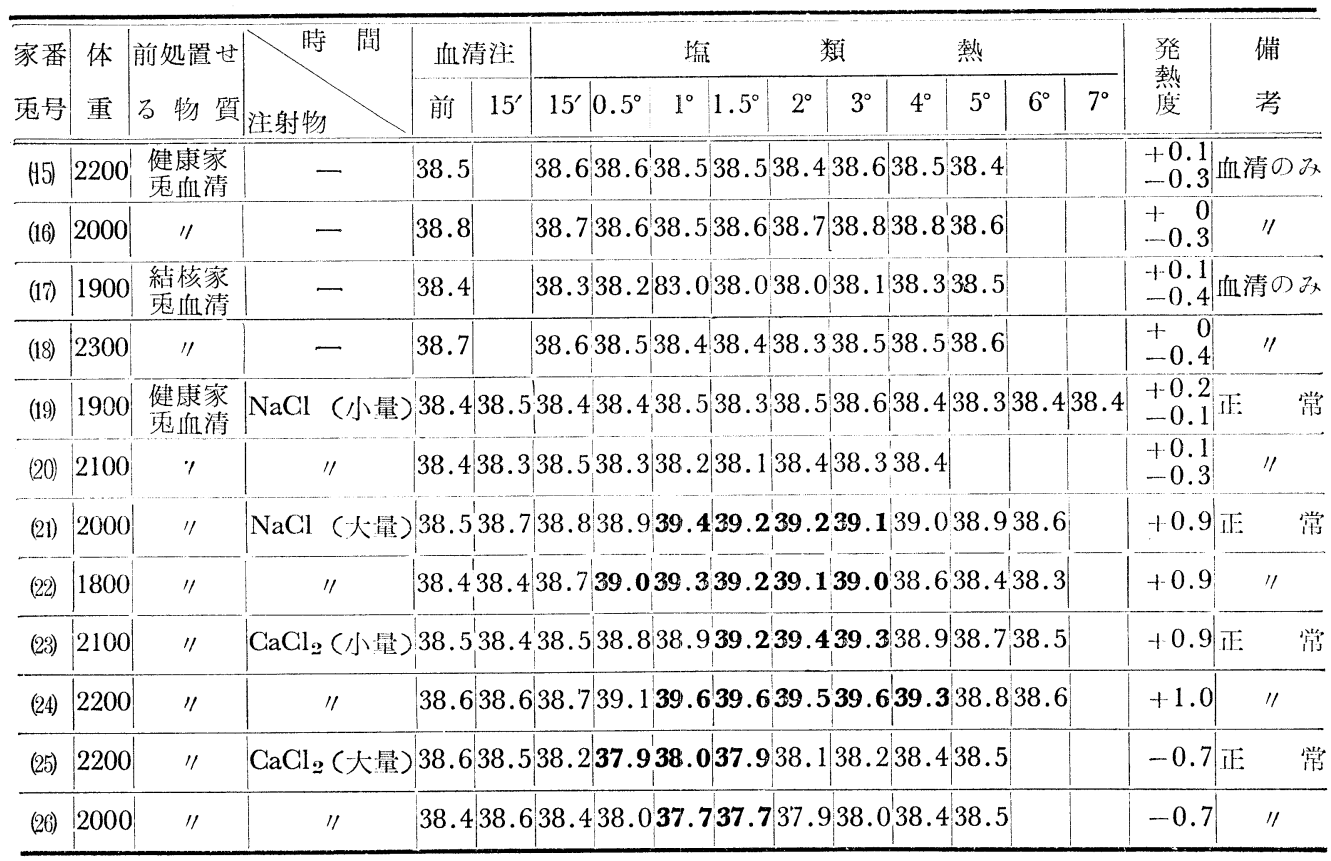

\section{第 1 節 感染初期結核家鬼の血清の作用}

正常家鬼工静脈血清及び結核家鬼血清を $3 \mathrm{cc} / \mathrm{kg}$ の割合に他健常家鬼に注射しても体温に何等変動を与え ないし，亦正常家鬼血清を同様に他健常家鬼清注前処置しても，その塩類熱反応に何等影響を与えないて とを確かめたので，感染初期結核家鬼(菌気管注入後 5 日目) の血清を $3 \mathrm{cc} / \mathrm{kg}$ の割合に他健常家鬼に静注前 処置して，その20分猃て $\mathrm{Na}$ 熱及び $\mathrm{Ca}$ 熱反応至検したが，正常家鬼血清の前処置或いは無処置の場合と何 等異ならない正常反応を呈することが分かつた。 即ちここでは重複を避ける為に第 7 表に Ca 熱反応の大量 注射例のみ表示したのであるが，乙の表に看られる上うに 2 羽の実験家禹共に刺㦸源注射猃 1 侍間から同 $2 \sim 3$ 時間後の間に於て正常家鬼の $\mathrm{Ca}$ 大量注射例同様にー0.8〜 - 0.9 $9^{\circ}$ の最大体温変動差を示す体温下降 ぶ見られた，従つてての時期の四静脈血清には，他体の $\mathrm{Na}$ 熱及び $\mathrm{Ca}$ 熱反応に影響を与える上うな作用は 全く認められないのである。

第 7 表 感染初期結核家鬼(菌気管注人後 5 日目) の血清尼以て前処置された正常家鬼の 前処置20分後に於ける $\mathrm{Ca}$ 熱 (大量注射例) (単位 ${ }^{\circ} \mathrm{C}$ ) (室温 $20 \sim 24^{\circ} \mathrm{C}$ )

\begin{tabular}{|c|c|c|c|c|c|c|c|c|c|c|c|c|c|c|}
\hline \multirow{2}{*}{$\begin{array}{l}\text { 家番 } \\
\text { 鬼号 }\end{array}$} & \multirow{2}{*}{$\begin{array}{l}\text { 体 } \\
\text { 隼 }\end{array}$} & \multirow{2}{*}{$\begin{array}{l}\text { 前処置 } \\
\text { 血 清 }\end{array}$} & \multirow{2}{*}{ 時 } & \multicolumn{2}{|c|}{ 血清注 } & \multicolumn{2}{|c|}{ 塩 } & \multicolumn{2}{|c|}{ 類 } & \multicolumn{3}{|c|}{ 熱 } & \multirow{2}{*}{$\begin{array}{l}\text { 発 } \\
\text { 熱 } \\
\text { 度 }\end{array}$} & \multirow{2}{*}{$\begin{array}{l}\text { 備 } \\
\text { 考 } \\
\end{array}$} \\
\hline & & & & 前 & $15^{\prime}$ & $15^{\prime} 0.5^{\circ}$ & $1^{\circ}$ & $1.5^{\circ}$ & $2^{\circ}$ & $3^{\circ}$ & $4^{\circ}$ & $5^{\circ}$ & & \\
\hline (27) & 1900 & 感 染 初 期 & $\mathrm{CaCl}_{2}$ (大量) & 38.6 & 38.5 & 38.438 .1 & 37.8 & 37.9 & 0.0 & 38.1 & 38.4 & 38.6 & -0.8 & 㱐: 掌 \\
\hline (28) & 1800 & ( 5 日目)血清 & "I & 38.5 & 38.4 & 38.438 .0 & 37.7 & 737.9 & 37.6 & 37.9 & $\overline{38.3}$ & $38 . \overline{4}$ & -0.9 & 11 \\
\hline
\end{tabular}


第 2 項 ツ反応陽転前期結核家鬼の血清の作用

前項と同様の方法で結核感染後17～19日目のツ反応陽転前期結核家鬼の耳静脈血清を $3 \mathrm{cc} / \mathrm{kg}$ の割合に他 健常家鬼に静注前処置して，その20分徐に前記方法を以て塩類熟を検した結果， $\mathrm{Na}$ 熱反応に 於ては先の小 量注射に対して反応を示さないととは正常反応と同様であつたが，大量注射に対しては正常と趣を異にして その発熱は低くて傾向を示すのみであつた，亦 $\mathrm{Ca}$ 熱反応に於てはその小量注射に対して発熱は低く傾向を 示すのみで，大量注射に対しても体温の下降度の低いとてろの異常反応の様相が窅えた．即ちとの成績の列 挙は重複するところが多いので (第 1 章, 第 2 節, 第 2 項参照), Ca 熱反応の大量注射例のみを第 8 表とし て表示したのであるが，実験家鬼 2 羽の中 1 例は注射後 $1 \sim 2$ 時間の間に於て最大 $-0.8^{\circ} \mathrm{C}$ の有意義性の体 温下降を示したが，他の 1 例は注射捘 2 時間に於て最大 $-0.5^{\circ} \mathrm{C} の$ 正常動摇圈内の体温下降を示したに過ざ なかつた，従つてての時期に至ると，結核家鬼の耳静脈血清には $\mathrm{Na}$ 熱及ひ $\mathrm{Ca}$ 熱它抑制するような作用が 敕度ながら出現すると言うととが出来ると思う。

第 8 表 ツ反応陽転前期結核家雨（菌気管注入後17〜19日目）の血清を以て前処置された 正常家鬼の前処置20分後に於け万 $\mathrm{Ca}$ 熱 (大量注射例) (単位 ${ }^{\circ} \mathrm{C}$ ) (䆛温 $20 \sim 24^{\circ} \mathrm{C}$ )

\begin{tabular}{|c|c|c|c|c|c|c|c|c|c|c|c|c|c|c|c|}
\hline 家番 & 体 & \multirow{2}{*}{$\begin{array}{l}\text { 前 処 置 } \\
\text { Ifll } \quad \text { 清 }\end{array}$} & \multirow{2}{*}{ |時 間 } & \multicolumn{2}{|c|}{ 血清注 } & \multicolumn{3}{|c|}{ 塩 } & \multicolumn{2}{|c|}{ 類 } & \multicolumn{3}{|c|}{ 熱 } & \multirow{2}{*}{ 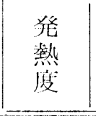 } & \multirow{2}{*}{$\begin{array}{l}\text { 備 } \\
\text { 考 } \\
\end{array}$} \\
\hline 兄号 & 重 & & & 前 & $15^{\prime}$ & $15^{\prime}$ & $0.5^{\circ}$ & $1^{\circ}$ & $1.5^{\circ}$ & $2^{\circ}$ & $3^{\circ}$ & $4^{\circ}$ & $5^{\circ}$ & & \\
\hline (29) & 1800 & \multirow{2}{*}{$\begin{array}{l}\text { ツ反応応陽転 } \\
\text { 前期家嵬血清 }\end{array}$} & $\mathrm{CaCl}_{2}$ (大崖 & 38. & 38. & 2 & 38.1 & 37.7 & 37.8 & 37.9 & 38.3 & 4 & 38.6 & -0.8 & \multirow{2}{*}{$\begin{array}{l}\text { 体温下降 } \\
\text { 体鼬下降 } \\
\text { 仳向 }\end{array}$} \\
\hline (30) & 1700 & & "I & 38. & 38.4 & 38.3 & 38.4 & 38.2 & 38.1 & 38.0 & 38.3 & 38.5 & - & -0.5 & \\
\hline
\end{tabular}

\section{第 3 項 ツ反応陽転期結核家鬼の血清の作用}

角項の実駼でツ 反応陽転前期結核家鬼の耳静脈血清には他健体の $\mathrm{Na}$ 熱及び $\mathrm{Ca}$ 熱反応考輅度ながら 抑制 するような作用が認められたのであるが，次とッ反応陽転後 3〜 5 日目の結核家鬼の耳静脈より採血し，乙

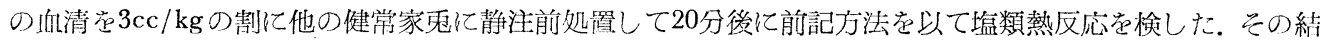
果は第 9 表に示されているように，Na 熱反応はその小量注射に対して正常動搯圈内の体温変動(1例は十

第 9 表 ツ反応陽転期絬核家农(ツ反応陽転後 3 ～ 5 日目) 血清を以て前処置された 正常家鬼の前処置 20 分後に於ける㙁類熱 (筸位 ${ }^{\circ} \mathrm{C}$ ) (室温 $20 \sim 24^{\circ} \mathrm{C}$ )

\begin{tabular}{|c|c|c|c|c|c|c|c|c|c|c|c|c|c|c|}
\hline \multirow{2}{*}{$\begin{array}{l}\text { 家番 } \\
\text { 鬼号 }\end{array}$} & \multirow{2}{*}{$\begin{array}{l}\text { 体 } \\
\text { 重 }\end{array}$} & \multirow{2}{*}{$\begin{array}{l}\text { 前 処置 } \\
\text { Ifl 清 }\end{array}$} & 時 & \multicolumn{2}{|c|}{ 血清注 } & \multicolumn{2}{|c|}{ 壏 } & \multicolumn{2}{|c|}{ 類 } & \multicolumn{3}{|l|}{ 熱 } & \multirow{2}{*}{$\begin{array}{l}\text { 発 } \\
\text { 熱 } \\
\text { 度 }\end{array}$} & \multirow{2}{*}{$\begin{array}{l}\text { 備 } \\
\text { 考 }\end{array}$} \\
\hline & & & 注:射物 & 前 & $15^{\prime}$ & $15^{\prime} 0.5^{\circ}$ & $1^{\circ}$ & $1.5^{\circ}$ & $2^{\circ}$ & $3^{\circ}$ & $4^{\circ}$ & $5^{\circ}$ & & \\
\hline (31) & 2100 & \multirow{5}{*}{ ッ反灾陽 } & $\mathrm{NaCl}$ (小量) & 38.4 & $38.6 \mid$ & 38.438 .5 & 38.4 & 438.3 & 38.4 & 38.6 & 38.7 & $7|38.8|$ & $\begin{array}{l}+0.4 \\
-0.1\end{array}$ & 無反店 \\
\hline (32) & 1700 & & 11 & 38.5 & 38.6 & 38.338 .2 & 38.2 & 38.2 & 38.4 & 38.4 & 38.5 & & $\begin{array}{l}+0.1 \\
-0.3\end{array}$ & "I \\
\hline (33) & 2000 & & $\mathrm{NaCl}$ (大量) & 38.6 & 38.7 & 38.638 .4 & 38.5 & 38.4 & 38.6 & 38.4 & 38.5 & 538.7 & $\begin{array}{l}+0.1 \\
-0.2\end{array}$ & 無 反 灾 \\
\hline (34) & 1800 & & "I & 38.4 & 38.5 & 38.438 .1 & 38.1 & 38.1 & 38.2 & 38.2 & 38.1 & 138.3 & $\begin{array}{l}+0.1 \\
-0.3\end{array}$ & 11 \\
\hline (35) & 2000 & & $\mathrm{CaCl}_{2}$ (小量) & 38.7 & 38.6 & 38.938 .9 & 38.6 & 38.4 & 38.3 & 38.4 & 38.3 & 338.6 & $\begin{array}{l}+0.2 \\
-0.4\end{array}$ & 無反芯 \\
\hline (36) & 1900 & \multirow[t]{3}{*}{ 血深 } & 11 & 38.5 & 38.5 & 38.738 .8 & 38.4 & 38.2 & 38.2 & 38.3 & 38.4 & 438.6 & $\begin{array}{r}+0.3 \\
-0.3 \\
\end{array}$ & "I \\
\hline (37) & 1900 & & $\mathrm{CaCl}_{2}$ (大量) & 38.6 & 38.5 & 38.638 .8 & 39.1 & 39.23 & 39.2 & 39.1 & 38.9 & 938.7 & $\begin{array}{l}+0.6 \\
-0.1\end{array}$ & 異常反㐫 \\
\hline \multirow[t]{2}{*}{ (38) } & 1900 & & " & 38.5 & 38.4 & 38.638 .4 & 38.9 & 39.2 & 39.1 & 38.9 & 38.4 & $4|38.5|$ & $\begin{array}{l}+0.7 \\
-0.1\end{array}$ & "1 \\
\hline & & & & & 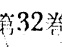 & 第 10 莦 & & & & & & & & \\
\hline
\end{tabular}






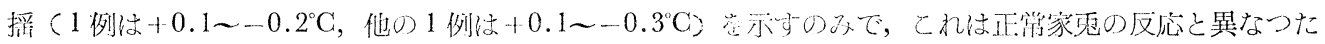

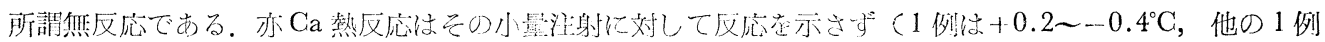

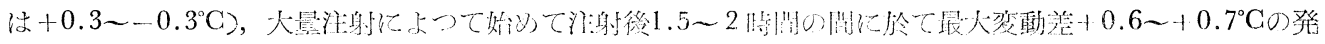

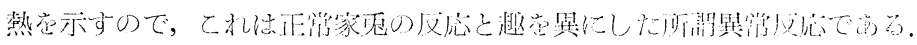

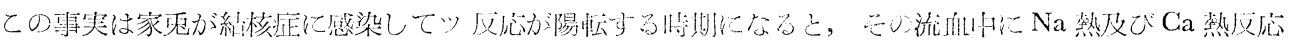

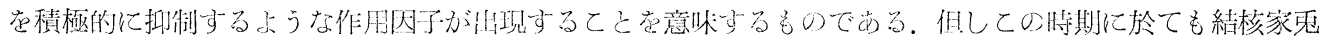

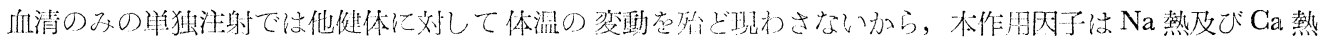

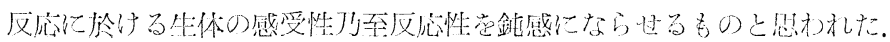

\section{第 2 節＼cjkstart結核家鬼血清肉に出現する塩類熱抑制性作用因子の理化学的性状}

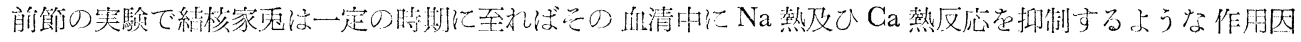

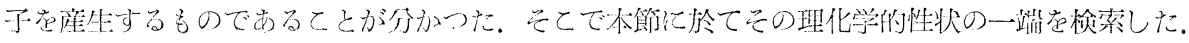

\section{第 1 項 エーテル溶解性害験}

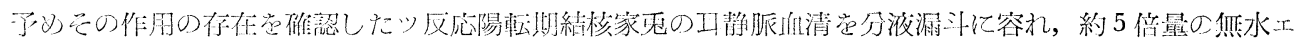

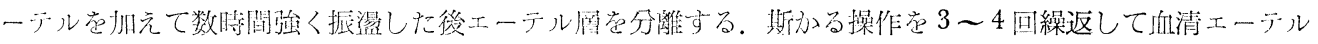

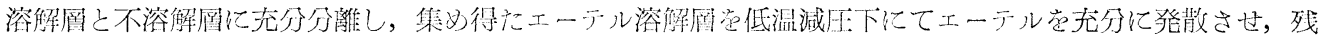

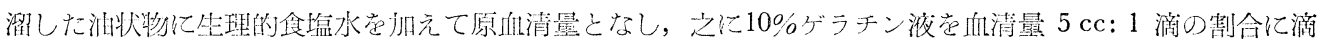
下して均質乳凮とする。一方エーテルに移行しなかつた部尔も同様て充分乾燥して粉末となし，之に原血清

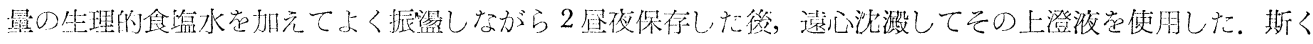

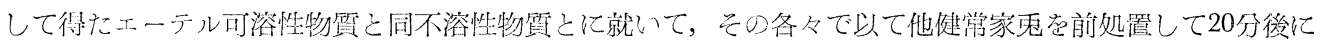
前述の方汇で $\mathrm{Na}$ 熱及び $\mathrm{Ca}$ 熱反応を检したところ，エーデル可溶性成分前処置例では正常塩類熱反応存旺 したが，エーテル不溶性成分前処䈯例では $\mathrm{Na}$ 熱反応に於てはその小量及び大量注射に対して反応定示さず，

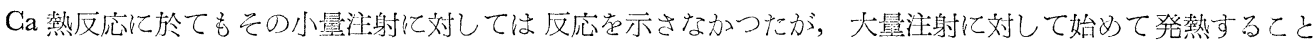

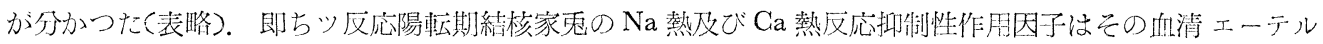
不溶性成分中に含まれている。

\section{第 2 項 血清蛋白分劃実験}

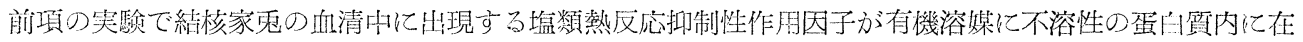
るととが分かつたので，更て之老アルブミンとグロブリンとに別けて奏験を行つた。予め本作周因子の存在

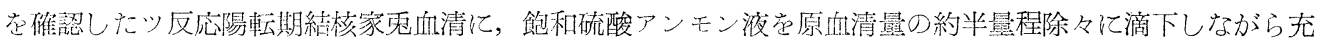

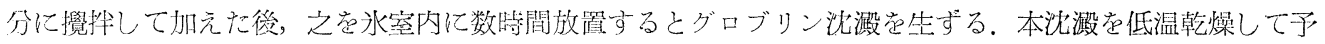
め正碓意点梌定したコロヂウム膜囊内に収容し，1週間前後流水中で透析して硫酸イオンが全く消失しでか

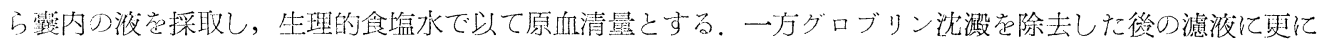

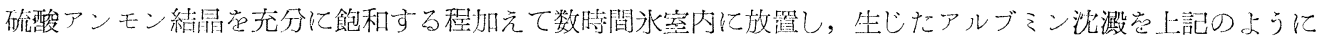

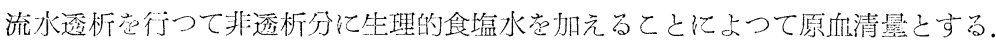

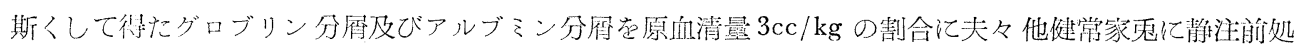

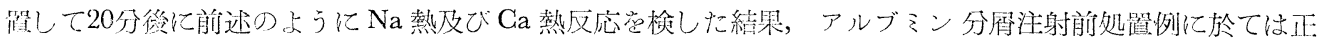

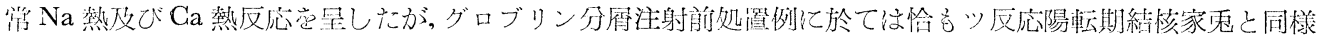

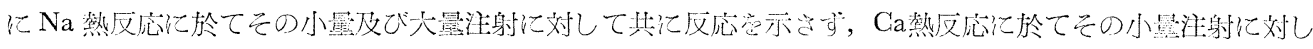

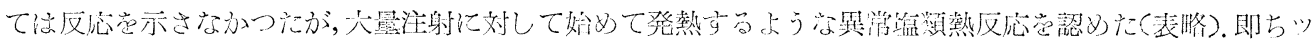

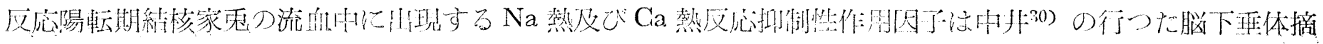




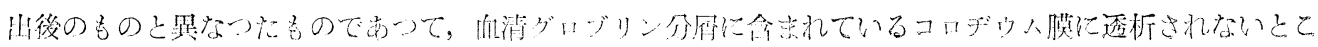
ろの蛋白体である。

\section{本章の小括}

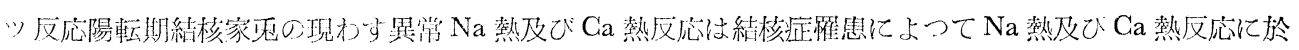

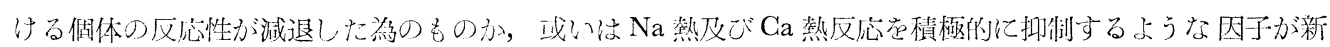

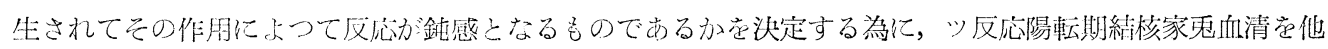

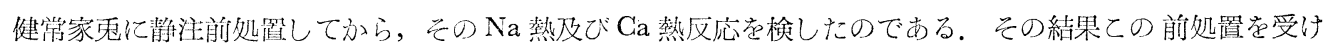
た家乘はツ反灾陽転期結核家鬼の现わ恶 $\mathrm{Na}$ 熱及び $\mathrm{Ca}$ 熱反応と全く同様な反灾を呈するが，一方結核家鬼

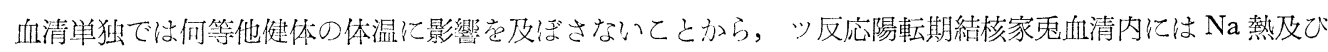
$\mathrm{Ca}$ 熱反応を積極的に抑制するような作用因子が産生されているものであるてとが分かつた。而して斯かる

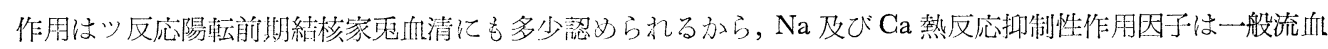

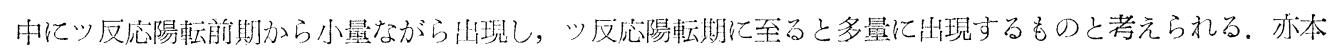

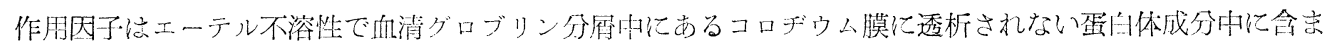
れているととが分かつた。

\section{第了章 結核家鬼流血中に出瑅する塩類熱抑制性作用因子の産出臟器}

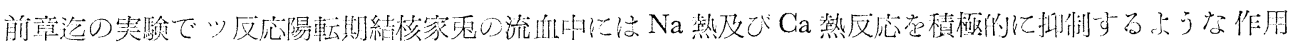

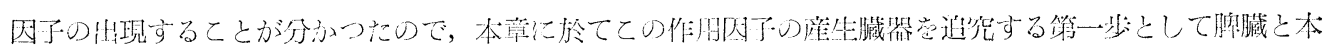
作用団子の関係存梌䒺することとした。

\section{第 1 節 結核家鬼の脾臟摘出実験}

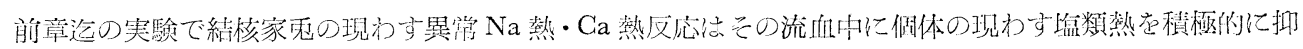

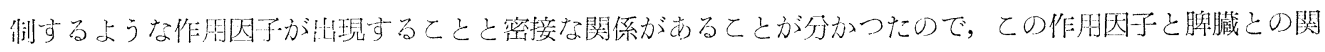

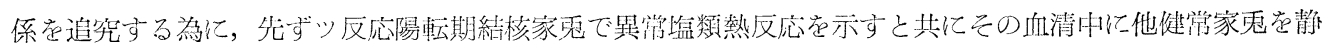
注前処置することによつて異学塩類熱反応党起させる作用か確認された時期にその脾臟を摘出して, 脾摘 2

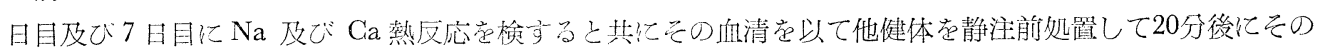
$\mathrm{Na}$ 熱及び $\mathrm{Ca}$ 蓺反応に及!ぶす影響定検した。 その結果，第10表に示されているように脾摘 2 日目に於ける 塩類熱は $\mathrm{Na}$ 熱反応に於てその小最注射に刘して+0.1〜 - $0.4^{\circ} \mathrm{C}$ の体温変動を示すのみで所謂無反応であつ

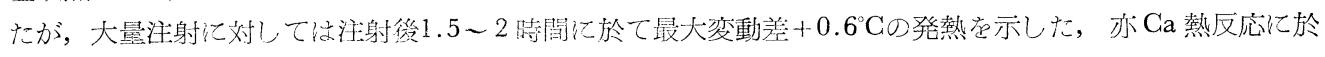

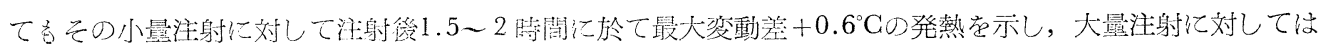

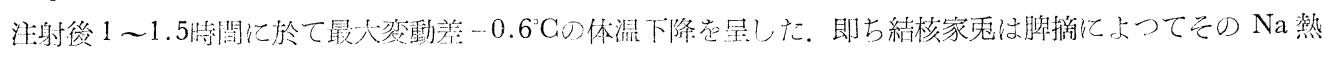

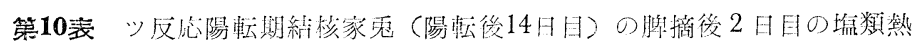
(准位 ${ }^{\circ} \mathrm{C}$ ) (空湿20－24 ${ }^{\circ} \mathrm{C}$ )

\begin{tabular}{|c|c|c|c|c|c|c|c|c|c|c|c|c|c|}
\hline \multirow{2}{*}{$\begin{array}{l}\text { 家番 } \\
\text { 压号 }\end{array}$} & \multirow{2}{*}{$\begin{array}{l}\text { 体 } \\
\text { 重 }\end{array}$} & \multirow{2}{*}{ 時 } & \multicolumn{4}{|c|}{ 程 } & \multicolumn{2}{|l|}{ 類 } & \multicolumn{3}{|l|}{ 熱 } & \multirow{2}{*}{$\begin{array}{l}\text { 発 } \\
\text { 熱 } \\
\text { 洹 }\end{array}$} & \multirow{2}{*}{$\begin{array}{l}\text { 倩 } \\
\text { 考 }\end{array}$} \\
\hline & & & 前 & $15^{\prime}$ & $0.5^{\circ}$ & $1^{\circ}$ & $1.5^{\circ}$ & $2^{\circ}$ & $3^{\circ}$ & $4^{\circ}$ & $5^{\circ}$ & & \\
\hline (5) & 1700 & $\mathrm{NaCl}$ (小昌) & 38.7 & 33.4 & 38.3 & 38.6 & 38.7 & 38.8 & 38.7 & 38.7 & 38.7 & $\begin{array}{l}+0.1 \\
-0.4\end{array}$ & 正常 \\
\hline (7) & 1700 & $\mathrm{NaCl}$ (大lit) & 38.6 & 38.4 & 38.7 & 38.9 & 39.2 & 39.2 & 39.1 & 38.8 & 38.7 & $\begin{array}{l}+0.6 \\
-0.2\end{array}$ & 正常 \\
\hline (10) & 2200 & $\mathrm{CaCl}_{2}$ (小早) $\mid$ & 38.9 & 39.2 & 39.3 & 39.4 & 39.5 & 39.5 & 39.2 & 39.0 & 38.8 & $\begin{array}{l}+0.6 \\
-0.1 \\
\end{array}$ & 正常 \\
\hline (14) & 1800 & $\mathrm{CaCl}_{2}$ (人) & 38.8 & 38.5 & 38.3 & 38.2 & 38.2 & 38.4 & 38.7 & 38.8 & - & $\begin{array}{l}+\quad 0 \\
-0.6\end{array}$ & 正常 \\
\hline
\end{tabular}




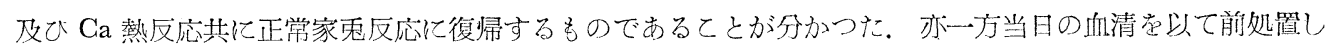
た他健常家鬼の $\mathrm{Na}$ 熱及び $\mathrm{Ca}$ 熱反応は全く正常家鬼の反応を示し，何等該血清による影響点受けないとと が分かつた(表略)，即ち結核家鬼の血清中に悓する塩類熱反応抑制性作胭因子も亦脾摘に上つて消失する ものと思われた。

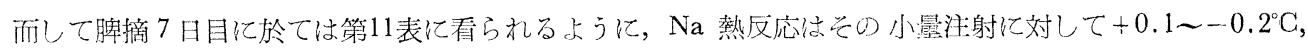

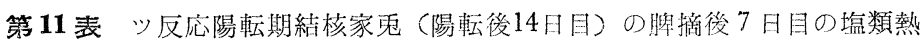
(酙储 $\mathrm{C}$ ) (室温 $20 \sim 24^{\circ} \mathrm{C}$ )

\begin{tabular}{|c|c|c|c|c|c|c|c|c|c|c|c|c|}
\hline \multirow{2}{*}{$\begin{array}{l}\text { 家番 } \\
\text { 雭昂 }\end{array}$} & \multirow{2}{*}{$\begin{array}{l}\text { 休 } \\
\text { 重 }\end{array}$} & \multirow{2}{*}{ 時 間 } & \multicolumn{4}{|c|}{ 嫶 } & \multicolumn{4}{|c|}{ 䅡 } & \multirow{2}{*}{$\begin{array}{l}\text { 発 } \\
\text { 熱 } \\
\text { 度 }\end{array}$} & \multirow{2}{*}{$\begin{array}{l}\text { 猜 } \\
\text { 考 }\end{array}$} \\
\hline & & & 尚if & $15^{\prime}$ & $0.5^{\circ}$ & $1^{\circ}$ & $1.5^{\circ}$ & $2^{\circ}$ & $3^{\circ}$ & $4^{\circ}$ & & \\
\hline (5) & 1700 & $\mathrm{NaCl}$ (小量) & 38.6 & 38.4 & 38.5 & 38.7 & 38.6 & 38.5 & 38.5 & 38.6 & $\begin{array}{l}+0.1 \\
-0.2\end{array}$ & 無反忘 \\
\hline (7) & 1600 & $\mathrm{NaCl}$ (大量) & 38.7 & 38.9 & 38.9 & 38.9 & 38.7 & 38.8 & 38.8 & 38.7 & $\begin{array}{r}+0.2 \\
-\quad 0 \\
\end{array}$ & "I \\
\hline (10) & 2200 & $\mathrm{CaCl}_{2}$ (小量) & 38.7 & 38.6 & 38.4 & 38.6 & 38.4 & 38.7 & 38.8 & 38.7 & $\begin{array}{l}+0.1 \\
-0.3 \\
\end{array}$ & "I \\
\hline (14) & 1800 & $\mathrm{CaCl}_{2}$ (大量) & 38.7 & 38.7 & 39.0 & 29.1 & 38.9 & 39.0 & 38.8 & 38.8 & $\begin{array}{r}+0.4 \\
-\quad 0 \\
\end{array}$ & 11 \\
\hline
\end{tabular}

大量注射に対しても $+0.2 \sim-0{ }^{\circ} \mathrm{C} の$ 正常動摇圈内の体温变動菓星し，亦 $\mathrm{Ca}$ 熱反応もその小最注射に刘して $+0.1 \sim-0.3^{\circ} \mathrm{C}$ ，大量注射に対して $0.4 \sim-0{ }^{\circ} \mathrm{C}$ 正常動摇圈内の体温変動走示すに過丸゙なかつた。即ら 脾摘 7 日目に於ては Na 熱及び $\mathrm{Ca}$ 熱反応は共に再び釺くなつて反応を示さなくなる。亦その血清処琵に上

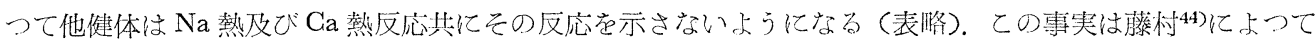
明らかにされたととろであるが，脾摘によつて甲状腺及び上皮小体の機能変調が起つて，その変調时状腺か

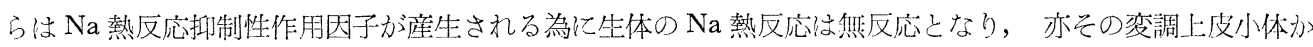

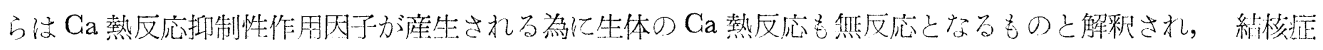
と怔無関係である。

\section{箒 2 節 結核家兔脾静脈血中の塩類熱抑制性作用因子の出現}

結核家鬼血清中に於ける $\mathrm{Na}$ 熱・Ca 熱反応抑制性作用因子がその脾臓加ら産生されるものであるとすれで゙， 一般流血中に本因子が多少とも出現するツ反応陽転前期結核家鬼の脾静脈血中には本因子が著眀に涊》られ る篦であるので, 脾臓が本因子の産生藏器である証明の一つとして脾静脈血の作用を検索することとした。 即ちツ反応陽転前期結核家鬼つ流血中には，Na 熱及び $\mathrm{Ca}$ 熱在反応多少とも抑制する作用があるが，ツ反応

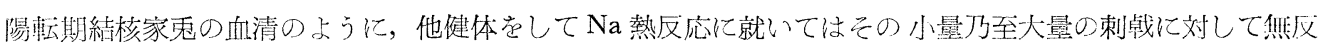

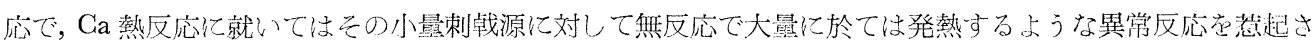

第12表 ツ反応陽転前期絬核家鬼（菌気管注入後18－19日目）の脾静脈血清党以て前処置された 正常家鬼の前処置後20分後に於ける塩類熱 (算位 ${ }^{\circ} \mathrm{C}$ ) (窒温 $20 \sim 24^{\circ} \mathrm{C}$ )

\begin{tabular}{|c|c|c|c|c|c|c|c|c|c|c|c|c|c|c|c|}
\hline 家番 & 体 & 前処置 & 時 間 & 血清 & 青注: & & & 懏 & 粽 & & 熱 & & & 発 & 啃 \\
\hline 压号 & 重 & 血 清 & & 前 & $15^{\prime}$ & $15^{\prime}$ & $\left|0.5^{\circ}\right|$ & $1^{\circ}$ & $1.5^{\circ}$ & $2^{\circ}$ & $3^{\circ}$ & $4^{\circ}$ & $5^{\circ}$ & 筊 & 桨 \\
\hline (39) & 2000 & \multirow{4}{*}{$\begin{array}{l}\text { 叉反応陽 } \\
\text { 転前期家 } \\
\text { 需脾静脈 } \\
\text { 血清 }\end{array}$} & $\mathrm{NaCl}$ (小最) & 38.7 & 38.4 & 38.5 & 38.5 & 38.7 & 38.6 & 38.8 & 38.5 & 38.7 & 38.6 & $\begin{array}{l}+0.1 \\
-0.3 \\
\end{array}$ & 無反忍 \\
\hline (40) & 1900 & & $\mathrm{NaCl}$ (大量) & 38.6 & 38.5 & 38.3 & 38.2 & 38.4 & 38.5 & 38.4 & 38.6 & 38.5 & $38.5 \mid$ & $\begin{array}{l}+\quad 0 \\
-0.4\end{array}$ & $" 1$ \\
\hline (41) & 2100 & & $\mathrm{CaCl}_{2}$ (小量) & 38.3 & 38.2 & 38.2 & 38.1 & 38.2 & 38.4 & 38.4 & 38.3 & 38.13 & $\mid 38.2$ & $\begin{array}{l}+0.1 \\
-0.2 \\
\end{array}$ & "l \\
\hline (42) & 2000 & & $\mathrm{CaCl}_{2}$ (大量) & 38.5 & 38.3 & 38.5 & 38.8 & 39.1 & 39.2 & 39.2 & 39.0 & 38.8 & 38.6 & $\begin{array}{l}+0.7 \\
-0.2 \\
\end{array}$ & 奖 熱 \\
\hline
\end{tabular}


せる程に强力な作用は認められない，斯わっ時期(菌気管注入後18１9日目)の脾静脈血を採り，他健常家

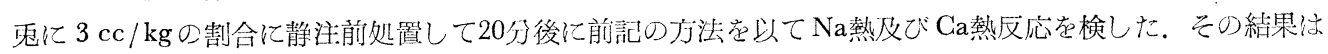
第12表に示されているように，Na熱反灾に於てはその小量注射に対して $+0.1 〜-0.3^{\circ} \mathrm{G}$ ，大量注射に刘し ても+0〜-0.4 $4^{\circ} \mathrm{C}$ と, 共正常動摇圈内の体温変動を示して無反応であつて， $\mathrm{Ca}$ 熱反応に於てもその小量 注射に対して $0.1 \sim-0.2^{\circ} \mathrm{C} の$ 正常動摇圈内の体温変動を示し，大量注射に対して始めて注射幑 $1 \sim 2$ 時間 に於て最大変動差 $+0.7^{\circ} \mathrm{C} の$ 発熱を示した。 これはツ反応陽転期結核家鬼の血清の作用効果と全く同じであ つた。 即ち一般流血中には Na熱・Ca熱反応抑制作用が比較的軽度に認められるに過ぎないッ反応陽転前期 結核家鬼の脾静脈血清には本作用が著明に認められることから，本作用因子は脾蔵办ら産生されるものであ るととが確东となつたと信ずるのである。

\section{第 3 節 結核家秃脾贜の他健常家鬼への移植実験}

本章第 1 節に於てッ反応陽転期結核家鬼の脾臟在摘出するてとによつて，その流向中に Na熱・Ca熱反応

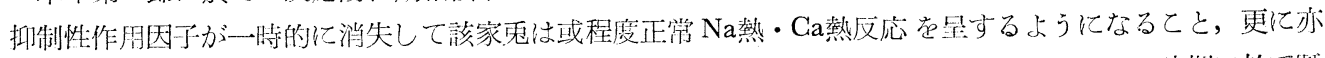

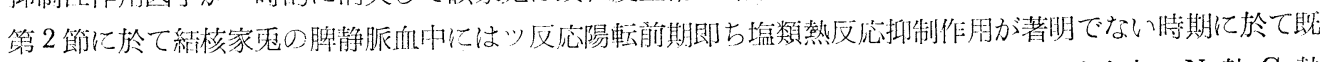

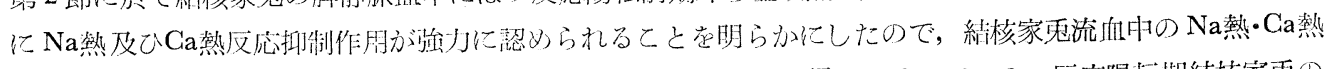

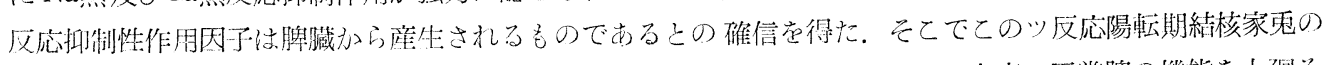

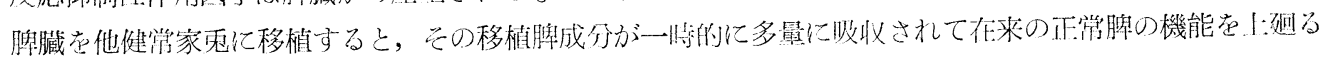
為に，被移植家电には異学 $\mathrm{Na}$ 熱・Ca熱反店が起る可能性がある。

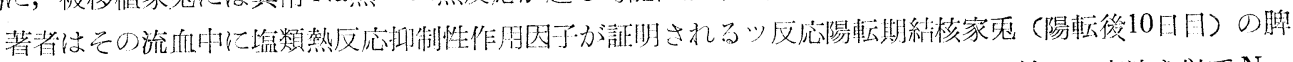

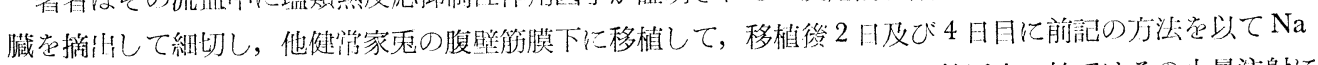

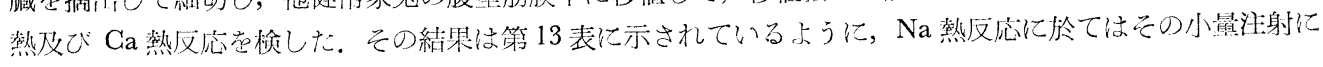

第13表 ツ反応陽転期結核家鬼脾㵴在移植された健常家匛の㙁類熱 (肖位 ${ }^{\circ} \mathrm{C}$ ) (室温 $20 \sim 24^{\circ} \mathrm{C}$ )

\begin{tabular}{|c|c|c|c|c|c|c|c|c|c|c|c|c|}
\hline 家番 & 体 & 時 閻 & & 嫶 & 燐 & & & 熱 & & & 発 & 備 \\
\hline 禹号 & 重 & 注射物 & 前 & $15^{\prime} 0.5^{\circ}$ & $1^{\circ} 1.5^{\circ}$ & $2^{\circ}$ & $3^{\circ}$ & $4^{\circ}$ & $5^{\circ}$ & $6^{\circ}$ & 度 & 考 \\
\hline (43) & 1900 & $\mathrm{NaCl}$ (小量) & 38.6 & 38.538 .3 & 38.438 .3 & 38.5 & 38.63 & 38.6 & 38.5 & & $\begin{array}{l}+\quad 0 \\
-0.3 \\
\end{array}$ & 無 反応 \\
\hline (43) & 11 & $\mathrm{NaCl}$ (大量) & 38.4 & 38.538 .3 & 38.238 .4 & 38.3 & 38.43 & 8.5 & 38.5 & & $\begin{array}{l}+0.1 \\
-0.2 \\
\end{array}$ & 異常反応 \\
\hline (44) & 1800 & $\mathrm{CaCl}_{2}$ (小量) & 38.3 & 38.138 .2 & 38.038 .0 & 38.2 & 38.33 & 38.4 & 38.3 & & $\begin{array}{l}+0.1 \\
-0.3 \\
\end{array}$ & 異常反応 \\
\hline (44) & "I & $\mathrm{CaCl}_{2}$ (大量) & 38.1 & $38.6 \mathbf{3 8 . 9}$ & 39.139 .6 & 39.5 & 39.23 & .29 & 38.63 & 38.2 & +1.5 & 異常反応 \\
\hline
\end{tabular}

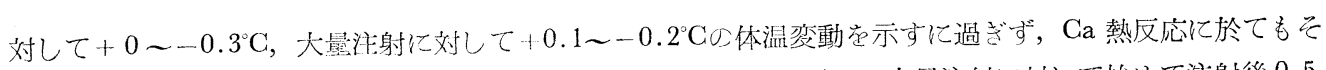

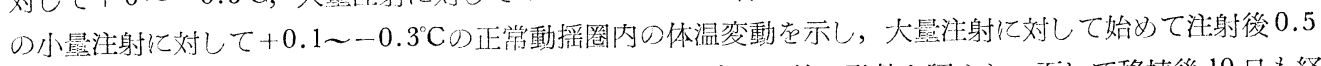

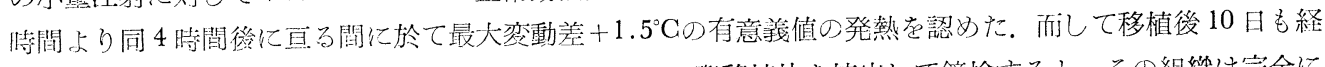

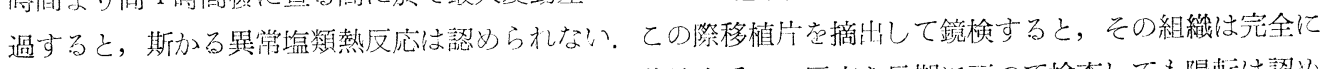

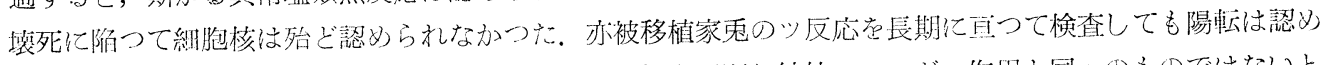
られな汃つたので, 移植脾の作用は生体のツ反応陽転作用即ち結核アレルギー作用と同一のきのではないと 思われる。

\section{第 4 節 結核家鬼に於ける健常家鬼脾臟の移植実験}

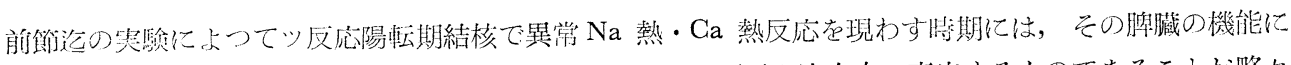

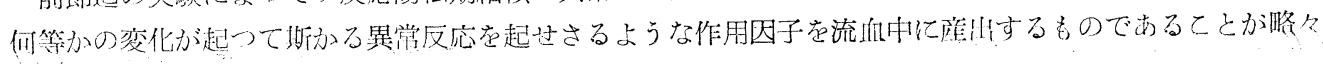


分かつた，而してとの脾臓の機能変化が量的のものか質的のものであるか子決定する方法として，德光188)

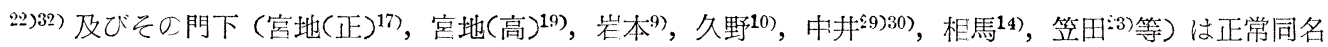
臟器移植実験を推奨して，若し機能の質的変化であるならばてれによつて異常反応が正調に復帰する可能性 があること芷強調した。

そこで著者はツ反応陽転期結核家鬼の腹壁筋膜下に細切した正常脾臓を移植して，移植後 2 日及び 4 日目 に前記の方法を以て $\mathrm{Na}$ 熱及び $\mathrm{Ca}$ 熱反応を検した結果， $\mathrm{Na}$ 熱反応に於てはその小量注射に対して反応を示 さないが，大量注射に対しては発熱を来たし，Ca熱反応に於てはその小量注射に対し発熱を示し，大量注射 に対しては体温の下降を来たした(表略). 即ち結核家鬼は正常脾㵴を移植することによつて正常家鬼に於け る塩類熱反応と全く同様な塩類熱反応を示すようになる。而してての正常反応の復活もその移植片の壊死に 陷る移植後約10日迄である。

この移植奏験によつて結核家鬼の脾臓機能には質的変化が起つているととが確実になつたものと思う。即 ち脾蔵機能の量的変化のみから考えるならば，異常塩類熱反応を呈する結核家鬼に正常脾臓を移植した場合， その移植脾臓成分が一時に多量に财収されて流血中に氾監するてとによつて正常反応に復すると言う事実と 前節の正常家鬼への結核家鬼脾㵴移植によつて異常塩類熱反応を呈する事実とは倛だ矛盾した結果となるか らである.

\section{本章の小括}

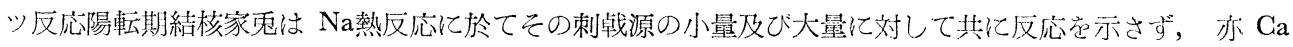
熱反応に於てもその刺戟源の小量に対して無反応で大量に対して発熱するような異常反応を呈するが，斯か る異常反応は結核家鬼の一般流血中に $\mathrm{Na}$ 熱及び $\mathrm{Ca}$ 熱反応を積極的に抑制するような作用因子ぶ産生され る為である，而して本作用因子の産生臟器を検索する為に，斯かる時期つ結核家鬼つ脾藏を摘出して脾摘 2 日目に塩類熱反応を検したところが，略々正常塩類熱反応に復することが分かつた。亦その家鬼脾摘 2 日 目) の血清を以て他健常家鬼を前処置しても，該健常家鬼の塩類熱反応に何等抑制的な影響を与えるここが

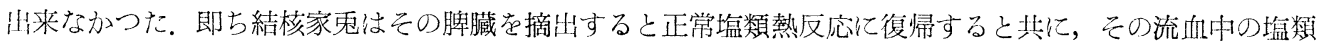
熱反応抑制性作用因子は消失するものであるから，乙の作用因子は結核家鬼の脾蔵加その流血中に産生さ れるものであることが略々確認された。

而して脾摘7日目に於て再び該家禹に就いて塩類熱反応 を検したとてろが，その Na熱及ひ $\mathrm{Ca}$ 熱反応は その刺戟源の小量及び大量に対して何れも無反応であつたばかりでなく，その血清にも明らかに他健常家兄 の Na熱及び Ca熱反応を無反応にするような積極的な作用が認められた，而してての事仿同門藤村 ${ }^{43}$ の脾 摘後の甲状腺 ( $\mathrm{Na}$ 熱反応に関与) 及び上皮小体 (Ca熱反応に関与) つ機能変調に関する研究結果に一致する ものであつて，結核症とは無関係に起る現象と解釈されるのである.

次に塩類熱反応抑制性作用因子が脾藏から産生されるものであれば，一般流血中にその存在が多少認めら れるツ反応陽転前期結核家鬼の脾静脈血中には多量に出現する筈であるので，斯かる時期の結核家鬼脾静脈 の血清に就いて塩類熱反応抑制性作用を検討した。 その結果，乙の血清を以て前処置された他健常家鬼はツ 反応陽転期結核家鬼耳静脈血清を以て前処置されたものと同様な塩類熱反応を示すてとが分かつたので，本 作用因子は脾蔵加ら産生されるものであることは更に確実となつた。

更にこの作用因子は脾臓がその機能の量的或いは質的変化を起した結果産生されるものであるとすれば, その脾臓の機能的変化の種別を検索する必要がある。そてで先ずッ反応陽転期結核家鬼(ツ反応陽転10日目) の脾臓を他健常家鬼に移植して, 移植後 2 日及び 4 日目にその塩類熱反応を検する実験を行つた結果, 被移 植家鬼は結核家鬼自体の現わす異常 $\mathrm{Na}$ 熱及び Ca熱反応を呈するととが分かつた。而してての被移植家鬼 の異常塩類熱反応は移植された結核家鬼脾㵴成分が一時に多量に吸収されて，その流血中の在来正常脾臓成 分を遙かに上迴つて氾濫する為であると解釈される, 即ち移植脾臟の壊死に陷る移植後10日にもなると斯か る異常反応は起らなくなるものである。亦被移植家鬼は 3 週間以上経過してもッ反応は遂に陰性に終るので, 
斯かる異常反応仙結核症に䍜急するととによるアレルギー反応夫自体に関係があるものでなく，脾臓が二次 的に機能的変化を招来した結果であると言い得る．次にツ反応陽転期結核家鬼に正常家鬼脾臓を移植して移 植後 2 日及び 4 日目に塩類熱反応を検する実験を行つた結果，被移植結核家鬼は正常家鬼同様の塩類熱反応 を呈するてとが分かつた，而してての場合移植された正常脾藏成分が一眭に多量に吸収されて流血中に汇濫 した為であると考えられる，従つて，若し結核家鬼脾臟か唯単なる機能の量的変化を起した為に異常塩類熱 反応を起すものであるとするならば，即ちその機能昂進の場合には結核家鬼に正常家鬼脾臟を移植しても尚 異常反応が起る䈏であり，亦その逆の機能減退の場合には正常家鬼に結核家鬼脾臓を移植しても尚正常反応 を呈する筈であるので，甚だ矛盾した結果となる．故に結核家鬼の流血中に出現を見る塩類熱反応抑制性作 用因子は，家夷が結核症に䍜患するてとによつてその脾蔵機能に質的変化を招来する結果産生されるもので あると言うととが出来ると思う。

\section{総括並びに考按}

緒論に於て既述したように，結核症のような全身病にあつては結核菌毒素がその生体葴器機能に種々影響 在及ばして臨床的一般症候を呈するものであるてとは周知の事実である。而してての場合, 従来は諸欌器機

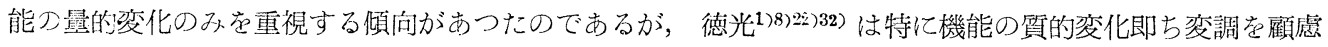

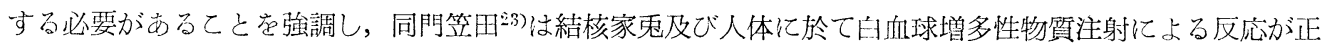
常と逆になることから，乙れは脾㵴機能の質的変化に基因するものであるととを明らかにした。著者は結核 家鬼に於て愳類熱反応を検索したとてろ，笠田の結果を支持する成績を得たので茲に報告した。

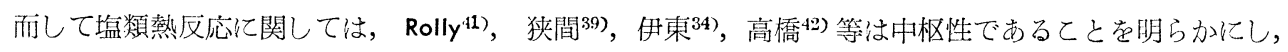

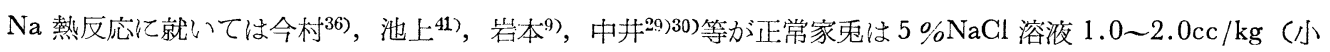
量) 注射によつては発熱しないが，同溶液 3.5〜 4 cc/ kg (大量) 注射によつて発熱したと言い，亦 $\mathrm{Ca}$ 熱

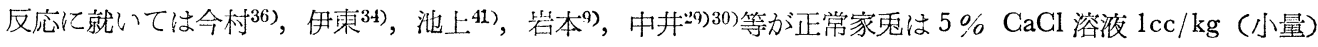
注射によつて発熱し，同溶液 $2 \mathrm{cc} / \mathrm{kg}$ (大量) 注射によつて体温下降を来たしたと言つている，著者も之を 追試し，正常家鬼に於ては $5 \% \mathrm{NaCl}$ 溶液 $1 \mathrm{cc} / \mathrm{kg}$ (小量)によつては何等反応を認めなかつたが，同溶淮 $4 \mathrm{cc} / \mathrm{kg}$ (大量) 注射によつて発熱するととを認め, 亦 $\mathrm{CaCl}_{2}$ 溶液 $1 \mathrm{cc} / \mathrm{kg}$ (小量) 注射によつて発熱を来た し, 同溶液 $4 \mathrm{cc} / \mathrm{kg}$ (大量) 注射によつて体温下降を来たすととを子小確認して，之を正常反応と仅称して 以下諸実験を行つた。

次いで家鬼住核菌浮游液 (1.0cc: $5 \mathrm{mg})$ を $0.5 \mathrm{cc} / \mathrm{kg}$ の割合に気管内注入を行つて感染させ，感染後各 期に於ける Na熱及び Ca熱反応を検した結果，感染初期（菌気管注入後 5 日目）に於ては $\mathrm{Na}$ 熱及び Ca熱 反応共に正常反応学呈したが，ツ反応陽転前期（菌気管注入後19２0日目）に於ては Na 熱反応は小量注射 の場合は勿論大量注射の場合もその体温上昇度が低く発熱傾向を示すのみとなり, 亦 $\mathrm{Ca}$ 熱反応は小量注射 によつてその発熱傾向を示し大量注射による体温下降もその傾向を示すのみであつた。 即ち Na熱及び Ca熱 反応共に鈍くなつてその偭向を示すに過ぎなかつた。 更にッ反応陽転期（菌気管注入後 22 24 日目にッ反 応住陽転するが，その後 3 ～ 5 日目) 亿於ては $\mathrm{Na}$ 熱反応は小量及び大量注射によつて全く反応を示さなく なり，亦 $\mathrm{Ca}$ 熱反応仙小量注射の場合無反応てあるが，大量注射の場合には逆に発熱するてとが分かつた。 斯かる異常塩類熱反応沈伊東 ${ }^{34)}$, 中井 ${ }^{29}$ が松果腺摘出家鬼化就いて Na 熱反応はその小量及び大量注射共に

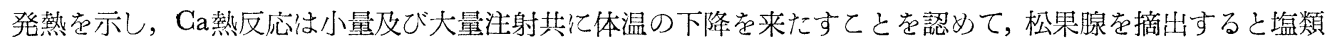

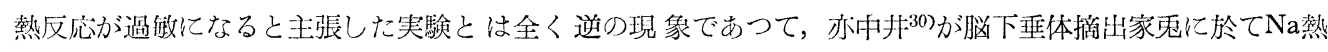

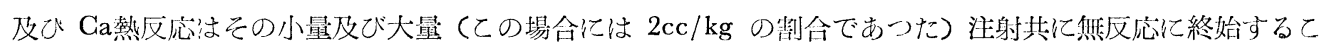

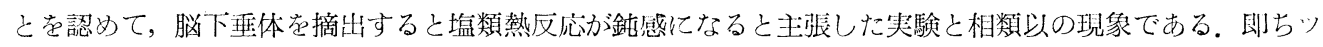
反応陽転期結核家鬼は塩類熱反応们対する反応性乃至感受性が鈍感になると言い得るのである.

而しててのような塩頙熱反応性か鈍感となることは，結核症惟患によつて個体の感受性が唯単に減退した 為つものか, 或いは積極的に塩頙熱反応を抑制するような機転が起つた為のるのかを検討する必要がある. 
そてでッ反応陽転期結核家鬼の耳静脈血清を採つて，3cc/ $\mathrm{kg}$ の割合に他健常家乘に静注しても体温に影響

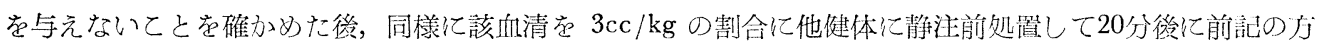
法を以て塩類熱反応を検したとてろが，恰もッ反応陽転期結核家鬼自体つ現わす塩類熟反応と全く同様な結

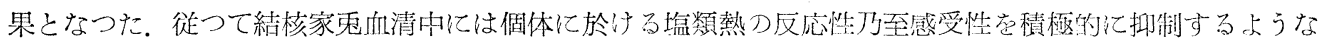

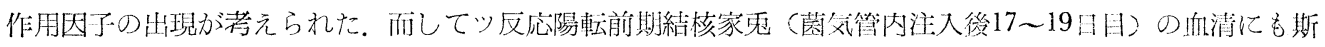

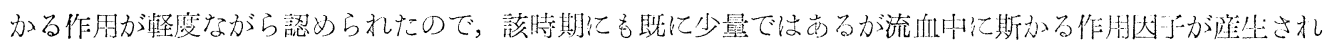
ているものである。

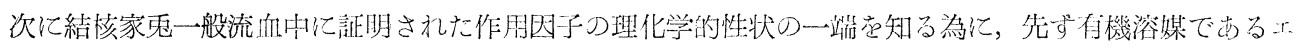

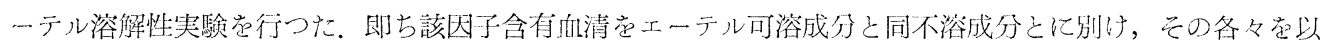

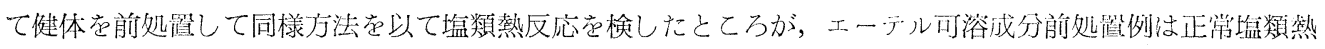

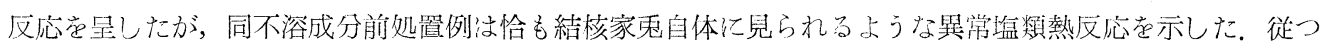
て本因子虻エーテル不溶性つ蛋白体成分中に潜んでいるととが分かつたので, 次に血清蛋白分劃実験を行つ

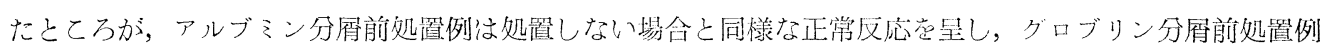

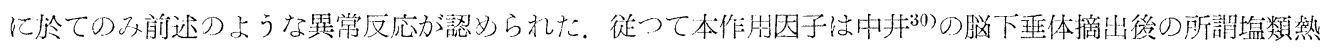
抑例性能働性物質 (エーテル不溶性・アルブミン分尿に含まる) と相異してエーテル不溶性のコロデウム膜 に透析されないグロブリン体に含有されているてとが分かつた。

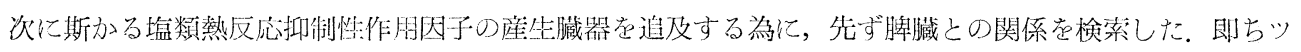
反応陽転期でその血清に塭頪熱反応抑制作朋があることを確涊された結核家鬼(陽転後14日)の脾藏を摘出

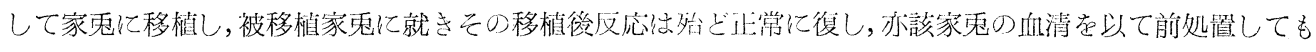

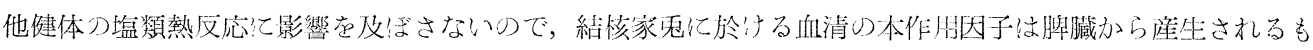

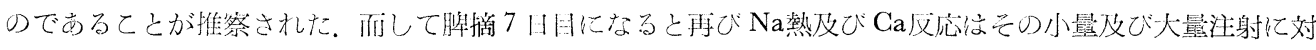

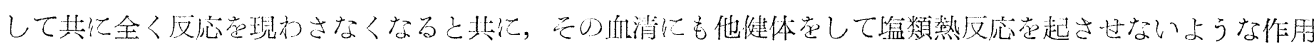

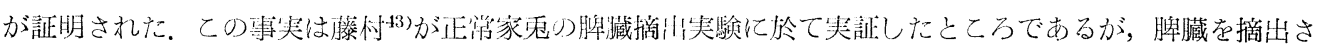
れた家鬼に於ては甲状腺及び上皮小体の機能が変調を起して，斯かか Na熱(4状腺が関与）及び_Ca熱（上

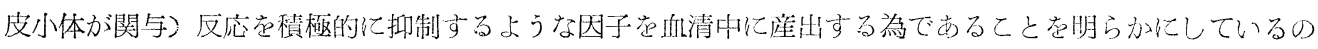
で，結核症とは無関係である。然らば結核家鬼伦ける塩類熱反応抑制性作用因子がその脾臓加ら産生され

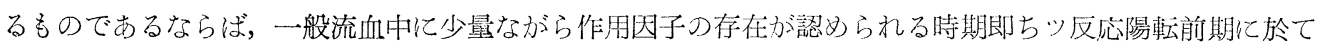

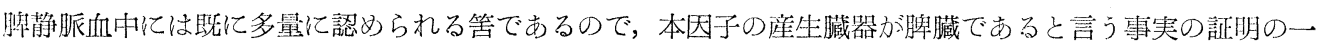
端として該時期結核家我の脾静脈血清の他健体塩類熱反応に及ぼす影響を検した。即ちこの脾静脈血清で前 処置された家鬼仙ツ反応陽枟期結核家鬼の血清で前処置された家鬼同様に，Na熱反応に於てはその小量及 び大量注射て対して共に無反応であつて，亦 Ga熱反応に於てもその小量注射に対しては反応を示さずに大

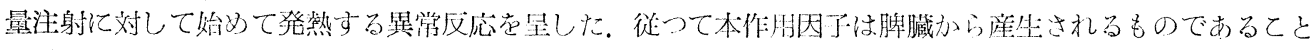
か確実になつたと信ずる。乙の事は笠田³3が白血球增多性物質の注射による生体の反応を指陑として結核症

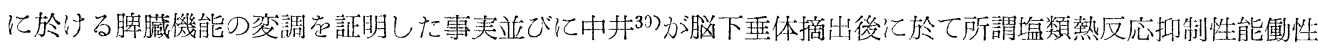
物質は脾裁から産生されるものであるてとを実証したのと類似する結果である。

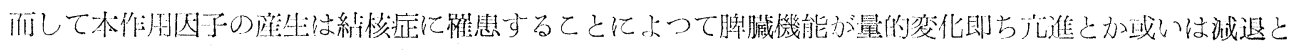

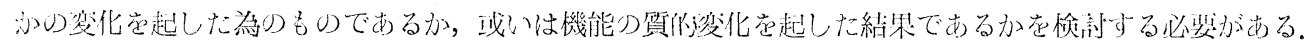

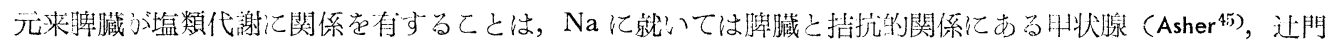

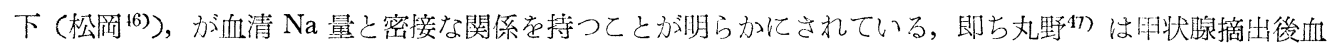

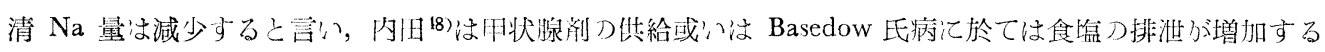

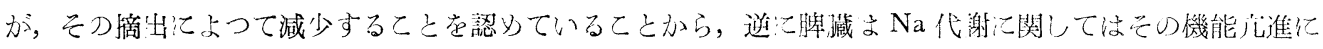
よつて血清 $\mathrm{Na}$ 量引減少することも推測されるつである。亦 $\mathrm{Ca}$ 代㴬汇関しては脾摘後血中 $\mathrm{Ca}$ 量が增加ず

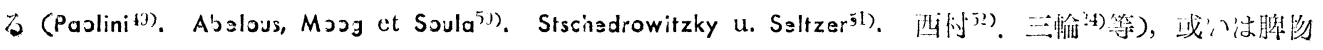




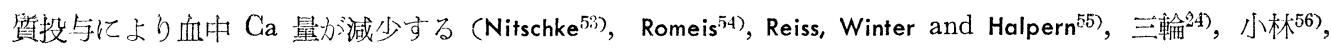

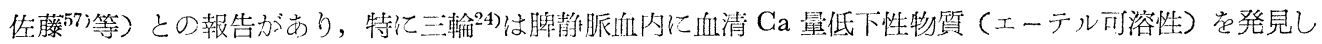
て上皮小体機能との拮抗似意義毫持つものであるとなし，之か脾ホルモンであると主張した。亦一方結核症

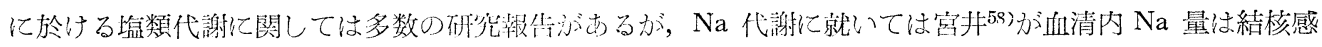

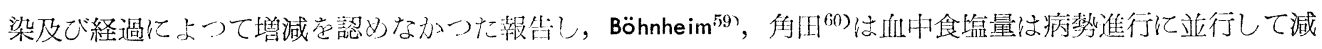
少すると報告しているに過ざない。亦結核症と $\mathrm{Ca}$ 代謝に関しては㷠に多数の研究報告があるが，その内

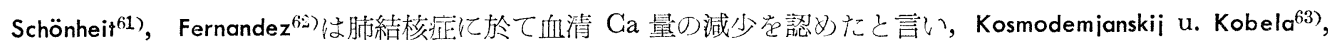

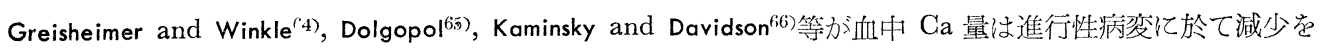

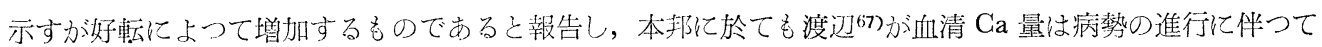

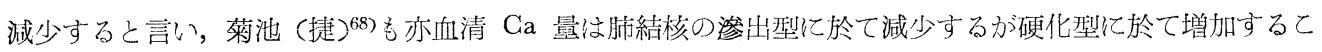

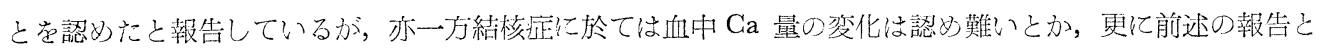
は逆に增加するとの報告るない解ではない，併しながら若し進行性結核症に於て血清 $\mathrm{Na}$ 量及び $\mathrm{Ca}$ 量か減 少するものであつて，之に脾藏機能のみが関与するものである之伇定すると，結核症に於ては三輸“4)等の所

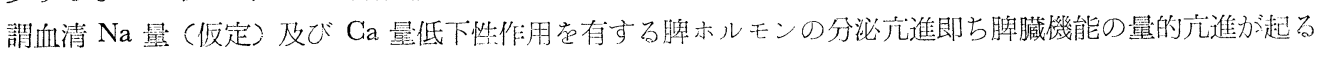
ものであるとも臆测されるのである。而して著者の夷験に於ける結核家鬼の脾臟加ら産生される塩類熱反心

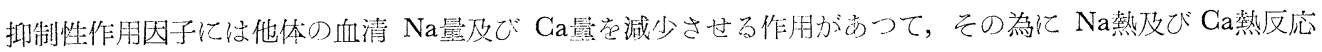
が起り難くなるととも推測されるのであるが，本作胉因子脑三輸24の所謂エーテル可溶性正常脾ホルモンと 異なつたエーデル不溶性の蛋白体であり，彩論血清内 $\mathrm{Na}$ 量及び $\mathrm{Ca}$ 量代謝飞関与するものであるか如何か は後つ実験に俟たなけれい゙ならない、唯三輸の所謂正常ホルモンではないととは確かであるので，本作用因 子が脾臟機能の変調産物であることは推測された。

そこで脾臟機能の質的変化即ち変調を証明する為に，その血清に他体をして異常塩類熱を起させる作用が あることを確認されたツ反応陽転期結核家鬼(ツ反応陽転後 10 日目)の脾蔵を摘出して他健常家鬼に移植した

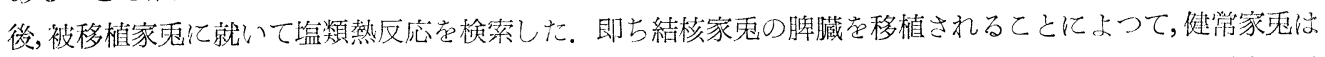
異常塩類熱反応を呈することが分かつたが，乙の場合被移植家身は移植後 3 週間以上経過してもッ反心陽 中云しな加つたので，てのような異常塩類熱反応結核アレルギーそのものに関係するものではなく，結核症

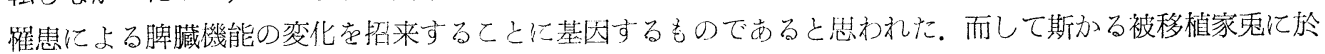

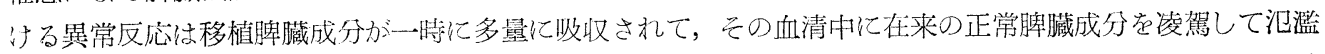

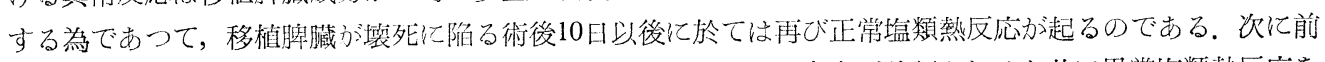

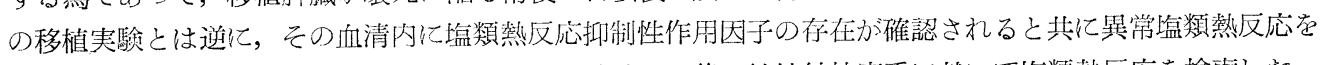
是するッ反応陽転期結核家鬼に正常家鬼脾藏を移植した後, 被植結核家鬼に就いて塩類熱反応を検絷した。

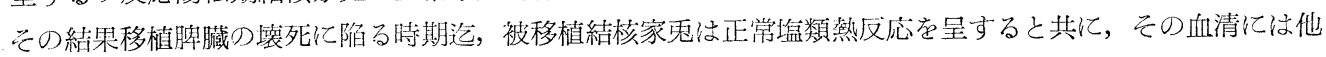
健体老して異常塩類熱反応を起させるような塩類熱抑制作用も亦認められないととが分かつた。㣭つてての

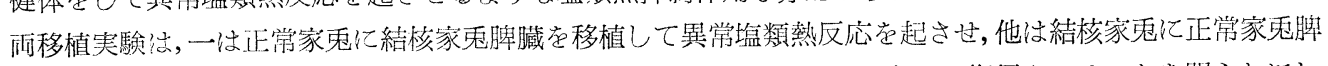

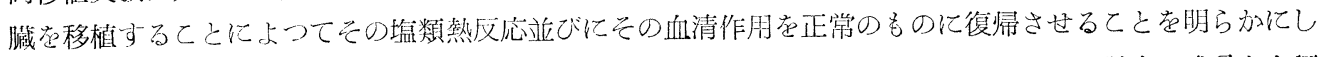

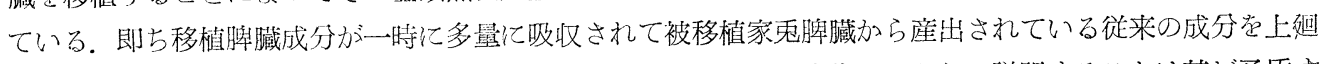

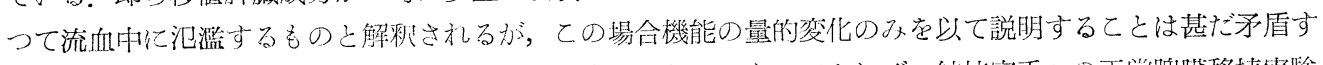

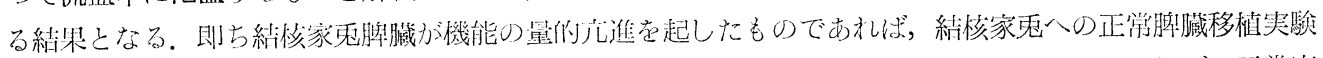

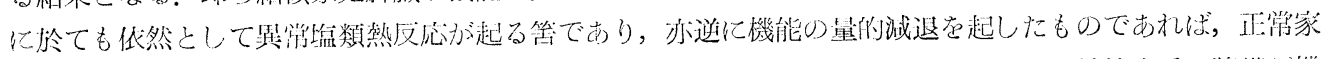

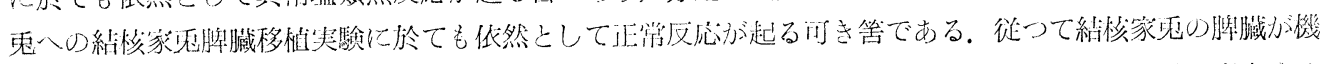

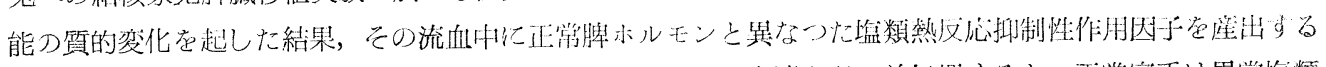

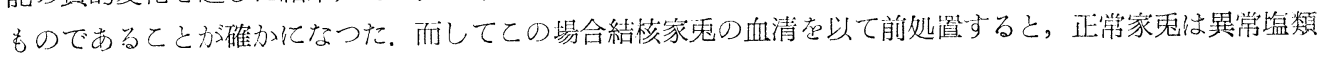
熱反応を現わすのであるが，乙れはをの血清内に産生されている脾藏変調産物力洞名藏器作用 (宮川 ${ }^{66)}$, 德

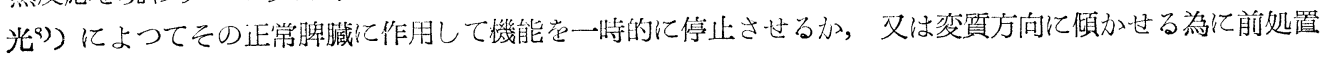


注射の血清作用がその塩類熱反応実跧に於て現われるものと解视されるのである。

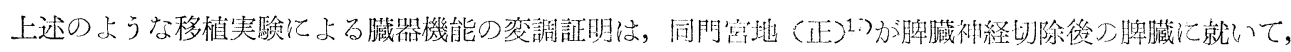

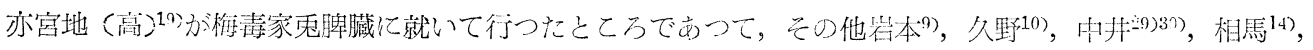

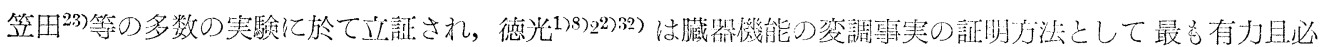
要なととであると強調した。

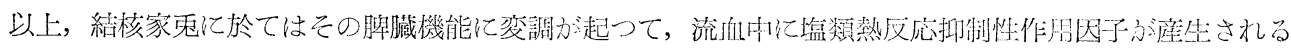

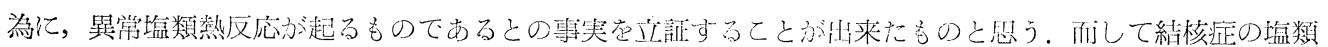

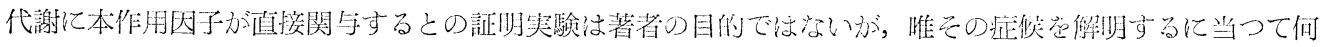
等加の意義存有するものと確信する。

\section{結 論}

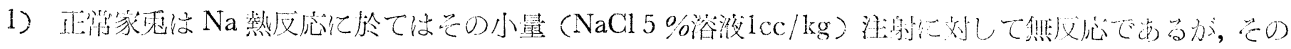

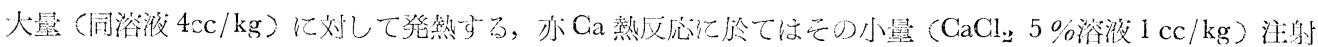

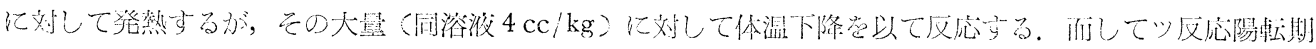

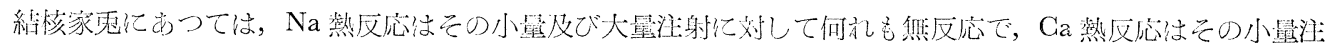
射に刘して热反応であるが，その大量注射に上つて始わて発熱するような極めて鈍感な㙁類熱反応が見られ た.

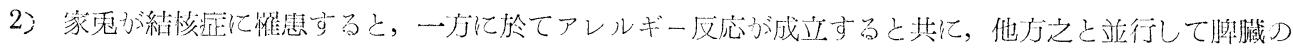

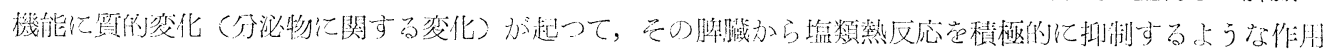

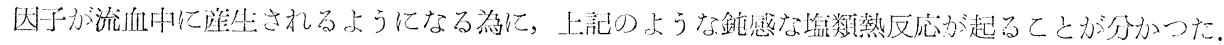

3）本作用因子はエーデン不溶步で，コロヂウム膜に透所されない血清グロブリン成分中含京れている ととまで証明するととが出来た。

\section{参 考 文 献}

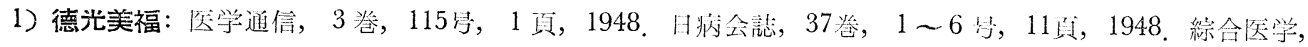
5 巻，206頁，1948。日内分泌誌，26巻，133頁， 1950 .

2) 豊田吟次：朝鮮选訫，26巻，937頁，1936. 日病会誌，23巻，44貢，1933.

3) 森有吉: 朝鮮图訫, 27 卷, 24 頁, 1937 .

4) 佐藤一雄: 朝鮮 医誌，29巻，794頁，同2326頁，1939.

5) 內山一夫: 朝鮮䀢誌，30巻，206貞，1940. 6) 增田 練藏: 朝鮮医誌，30巻，118頁，1940.

7) 金子雄治: 朝鮮医誌, 32巻, 373頁, 1942 .

8) 德说

美福：日病会誌，38巻，総会号，221頁，同地方会号，58頁，1949.

9) 岩本維三郎：米子医誌，1 巻, 58頁，1949. 10) 久野一郎: 米子医誌， 2 巻，70頁，同95頁，1950. 日内分泌誌，26巻, 139頁, 1950. 11) 中井剛太：日内分泌誌，26巻，177頁， 1950 . 12）中下静夫：日内分泌莣，27巻，14頁， 1951.

13) 网本治: 日内分泌誌，26巻，221頁，1950, 同誌，26巻 2291页， 1951. 誌，26巻，248頁，1951. 15）松田伸：日内分泌誌，27巻，45页，1951.

14) 相馬広明: 日内分泌 誌, 29巻, 559頁, 1939 .

17) 宮地正人: 朝鮮医誌，32卷，765頁， 1942.

16) 金南鎬: 朝䰻医 誌，31巻，51頁，同120頁，1941。 19）宮地高收：朝鮮医誌，30癷，1463页，1940。

18) 白川軋: 朝鮮医

泉：朝鮮医誌，33炎，485页， 1943. 21）白川童, 結城都夫：朝鲜医誌，31巻，229项，1941. 20) 岩下

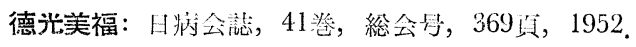
24) 三輪太郎: 京城紀要, 1 巻, 301賁, 1931. 26) 栗原剛: 朝鮮医誌, 31巻, 530頁, 1941.

28）長谷川武敏: 米子医誌， 1 巻，102頁， 1949.

30) 中井刷太: 日内分必恚，26巻，282頁，1950. 23) 筀田莮：日内分泌论，28恣，257頁，1952. 25）祛尾鉄之助：日病会誌，23巻，254頁， 1933. 27) 洪村学根: 日内分必誌，19卷，29員，同641頁 1944 . 29) 中井剛太: 口内分泌誌，26巻，42頁，1950. 31) 中下静夫：日内分泌誌，26巻，275貞，1951. 同芯，27卷，72員，1950。

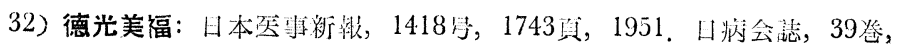


総会亭，226頁，同地方会号，183頁，1950. 同誌，40巻，総会号，393頁， 1951.

34) 伊東言麗夫:

朝鮮医誌，30巻，22頁， 1940

35) 若松元三郎: 皮膚紀要， 3 卷，77頁，1924.

36) 今村豊八:

日内科誌，17巻，673頁，1922. 日病会誌，20巻，230頁，1921.

37) 福田豊：日内科誌，13巻，905

頁，同917頁，1931。 38) 键山俊六：熊本医誌，9 巻，440頁，1933。 39 ) 狹問：伊東高麗夫 (朝鮮医誌，30巻，22頁，1940) 上り引用。 40) Freund：伊東高麗夫 (朝鮮医誌，30巻，22頁，1940) 上万引用. 41) 池上㹂一：日内分泌誌，19巻，63頁，同467頁，1544. 42) 高橋昌夫：岡山医大誌， 39巻, 256頁, 同850頁, 1927. 43) 藤村顕向: 日内分泌誌, 31巻, 459項, 1955 . 44) Rolly：

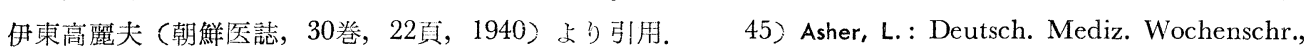
Bd. 27, S. 1252, 1911.46 ; 松岡㥆之助：日内分泌誌，5卷，1949貢，1929. 47) 丸野保：实験

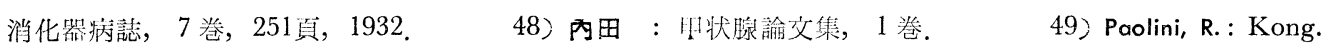
Zbl. ges. inn. Med. Bd. 37, 1913. u. Bd. 40, 1941. 50; Abelous, Moog et Soula: Berichte über d. ges. Physiol., Bd. 29, S. 579, $1925 . \quad$ 51) Stschedrowitzky, S.G., Seltzer, S.A.: Zschr. exp. Med., Bd. 52, S. 1892, 1928. Ibid., Bd. 53, S. 920，1929. 52) 西村俊一：日内分泌誌，4巻，1677项， 1928. 53) Nitschke : Zschr, f. d. ges. exp. Med., Bd. 65, S. 651, $1929 . \quad$ 54) Romeis: Arch. Entwg-Med. Bd. 39, 1913. Ibid., Bd. 40, $1914 . \quad$ 55; Reiss, Winter, K.A. u. Halpern, N.: Endocrinol., Vol. 5, p. 547, 1932. 56) 小林正義: 大阪医想，31巻，3371页，1932. 57> 佐藤安太郎：朝魹医誌，28巻，1309 頁，1928. 58）宮井茂吉：絬核，5卷，79頁，1927. 59) Böhnheim : Beitr. z. Klinik d. Tbk., Bd. 49, S. 233，1922. 60) 角田育之：絬核，8巻，528页，1930。 61) Schönheit, E.: Amer. Journ. Med. Science, Vol. 170, p. 689, $1925 . \quad$ 62) Fernandez, O.: Zbl. f. d. ges. Tbk-forschung, Bd. 24, S. 389, 1925. 63) Kosmodemianskii, S. u. Kobela, K.: Ibid., Bd. 27, S. 474, 1927 . 64) Greisheimer u. Winkle, C.V.: Amer. Rev. of Tuberculosis, Vol. 15, No. 2, $1924 . \quad$ 65) Dolgopol: Ibid., Vol. 20, p. 931，1929. 66; Kaminsky and Davidson：Ibid., Vol. 23, p. 442, 1931. 67) 渡辺三郎: 結核, 8 巻, 528頁, 1930。 68; 菊池捷二, 小田島権五郎, 三浦作次郎：東北医誌，15巻，488頁，1932。 69) 罟川米次: 笑験医誌, 6 巻, 291頁, 1922. 治療及び処方, 17巻, 1 頁, 同673頁, 1936. 